\title{
A Theoretical Case for Standardized Vesting Documents
}

\author{
CHAD J. POMEROY*
}

\begin{abstract}
Practitioners, real estate professionals, and lay people throughout the country rely on the recording system to provide critical information regarding ownership rights and claims. Indeed, the recording system acts as a virtually mandatory repository and disseminator of all potential parties' claims. This system, in turn, relies on these claimants and their agents to publicize their claims: property purchasers, lenders, lien-claimants, title companies, attorneys - these parties interact, make deals, make claims, order their affairs, and then record. The information system available to us, then, is only as good as what we make of it and what we put into it.

As such, it is surprising how little thought has been put into exactly what it is that we record. Should the mortgage of a lender in Ohio look like that of a lender in Florida? Should a deed from an individual in Texas differ from that of a corporation in Nevada? As it stands now, no one familiar with real estate law or commerce would expect different parties in different jurisdictions to record identical, or even similar, instruments. In an immediate sense, this heterogeneity of the recorded documents ("vesting heterogeneity") does not seem a good thing: parties utilizing the recording system generally seek to make known, or to discern, the same generic type of information - that is, evidence of claims upon property - so why are different forms and types of documents utilized all over the country?

This Article analyzes this vesting heterogeneity from a new perspective and concludes that it is, in fact, cause for significant concern. Vesting heterogeneity has arisen organically, growing with the recording system as they both evolved over time. This historical explanation does not, however, excuse the cost associated with such a lack of uniformity. Anyone seeking information with respect to any piece of property must navigate the complexities and uncertainties that arise because all such information is heterogeneous and, as a consequence, difficult to understand and utilize. This represents both an immediate transactional cost and an increased risk of ill-informed behavior.
\end{abstract}

* Assistant Professor of Law, St. Mary's University School of Law. 
This is particularly troublesome because this sort of cost-based concern arising from variability has a well-established analogue in property law that the law clearly desires to avoid. That analogue is the cost that would arise if property law were to permit unlimited property forms and gives rise to what is known as the numerus clausus theory. This theory explains the law's hostility toward new, or different, types of property and holds that such heterogeneity is not generally permitted because of the extremely high informational costs associated with such creativity.

This Article suggests that this common law concept can, and should, inform our analysis of vesting heterogeneity and that it precipitates strongly against such lack of uniformity. This is because the costs that drive the numerus clausus to hold that variability should be limited are strikingly similar to those created by variability of vesting documents. As such, this theory is relevant here such that the same analysis should be applied to vesting heterogeneity by asking whether a different (or "new") document is helpful enough to outweigh the informational costs inherent therein.

Based on this reasoning, this Article concludes that the law is wrong to systematically ignore heterogeneity in vesting documents. Instead, a numerus clausus type of analysis should be applied to new or different vesting documents to determine whether any inherent lack of uniformity is defensible. Where it is not, uniformity should be imposed.

\section{TABLE OF CONTENTS}

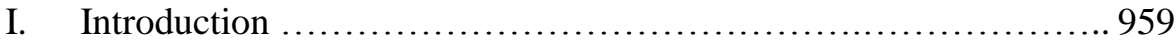

II. Vesting Heterogeneity ..................................... 962

A. The Rise of Heterogeneity .............................. 963

B. The Cost of Heterogeneity .............................. 969

III. The Numerus Clausus ........................................ 975

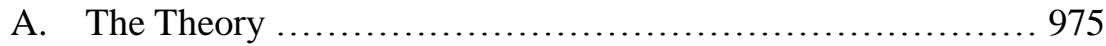

B. Analogous Costs ....................................... 980

1. Information Burdens Under the Numerus Clausus ......... 981

2. Information Burdens Compared to the Cost of Heterogeneity ....................................... 984

IV. A "Vesting Numerus Clausus" ................................... 987

A. A Proposed Numerus Clausus Analysis ....................... 987

B. How to Institute the Numerus Clausus Here .................. 995

V. Conclusion ............................................... 997 


\section{INTRODUCTION}

You are an associate at a mid-sized law firm in Ohio. One day, a senior partner comes to you with a thin file, consisting only of a survey and a preliminary title report. ${ }^{1}$ She drops it on your desk.

"My client wants to buy an old building in downtown Reno from a corporation called Blackacre, Inc. He's got to move fast, or he'll miss his chance. Take a look at the file and let me know by the end of the day if the seller has good title and whether my client should go forward."

On her way out, she adds, "Oh, yeah - the property is only worth about $\$ 50,000$, and the client doesn't want a big bill, so don't spend too much time on it." With that, she leaves.

"Reno, Nevada?" you ask yourself. You have never even been to Las Vegas for vacation - what do you know about real property in Nevada? You pick up the file and thumb through it.

Schedule $\mathrm{A}^{2}$ describes the tract and indicates that Blackacre, Inc., owns a "fee" interest in the property. So far, so good, you think, remembering Property I. ${ }^{3}$ Schedule A-1 is a little more confusing - it is a list of notes and requirements, but they all seem fairly routine-notes of property taxes due, requirements to issue the policy, and the like.

Then you start to review the Schedule $\mathrm{B}^{4}$ exceptions. Part I of that schedule seems routine - it lists easements, special assessments, and the like. ${ }^{5}$ This is all familiar stuff, and once you review the survey to make sure none of the easements run through the middle of the building, none of it gives you much heartburn. But then you get to Part II. That section of the report contains a long list of decidedly non-uniform items. Some of them, like two tax liens owing to the State of Nevada, are not too disconcerting - you know what they are, and you know that such things are generally paid in connection with a sale. Some of the exceptions, however,

1. A preliminary title report is the initial informational sheet prepared by a title insurance company that sets forth relevant issues affecting title. See 1 C.J.S. Abstracts of Title $§ 2$ (2011). It does not have the legal consequences of an abstract of title, upon which one can legally rely, and is primarily used by title insurance companies as a way to induce potential stake holders to purchase insurance. See id. at $\S \S 2,21$.

2. See, e.g., Am. Land Title Ass'N Owner's Policy of Title Ins., Schedule A (2006), available at $\mathrm{http}: / / \mathrm{www}$.alta.org/forms/.

3. A fee simple absolute is the most complete form of ownership available to private parties See JESSE DUKEMINIER, PROPERTY 193-94 (7th ed. 2010). It is certainly what your client would want.

4. See, e.g., Am. LANd Title Ass'N OwneR's Policy Of Title Ins., Schedule B (2006), available at $\mathrm{http}: / / \mathrm{www}$.alta.org/forms/.

5. See, e.g., id. 
are less clear. One, in particular, indicates that there is a $\$ 40,000$ Deed of Trust owing to an individual. You remember reading about deeds of trust in law school and think that they are more or less the same thing as mortgages, but in your three years of practice, you have only seen mortgages (the instruments used in the state of Ohio).

So, you do your best. You draft a short and concise memorandum indicating to the partner that the seller appears to have a fee simple absolute encumbered by a number of minor tax liens and a larger deed of trust. So long as these encumbrances are cleared off as part of the closing, ${ }^{6}$ you conclude, her client should be in good shape. You hand the memo in and forget about it.

Eighteen months later, the partner storms into your office. "My client's been sued! What did you do?!"

After calming down a bit, she explains the situation: the trust deed lender claims that its lien still has priority, and on top of that, a creditor of the prior owner (from whom your client's seller bought the property five years ago) claims he still has an interest. Both have sued your client.

"Didn't you check these issues out?" the partner asks. "Didn't you tell me we could buy from this seller?"

You try to explain-you relied on the preliminary report and what it told you. She had told you to be brief and efficient, so you had not ordered the underlying documents from the title company, or devoted a lot of time to researching Nevada forms and documents.

"But what about these claims?" she insists. "Even if you didn't see them, don't the recorded documents protect us? Don't they limit what these plaintiffs can do at this point?"

You start to say "yes" to defend yourself, but you stop. You do not know. You have never seen an actual deed of trust, and you simply assumed that the seller had fee simple by way of a special warranty deed or some equivalent to that local document. In truth, you do not know how the seller got the title, and you do not know what rights her creditors might still have. All you know is that there are numerous documents affecting the parcel that may be entirely unlike the ones you have previously seen and

6. Most sales of real property are handled by an escrow agent utilizing an escrow account. Such an account is "generally held in the name of the depositor and an escrow agent which is returnable to the depositor or paid to third persons on the fulfillment of escrow condition." BLACK'S LAW DICTIONARY 378 (6th ed. 1997). In effect, this requires parties, upon the pain of losing deposited funds, to accomplish contractual or other duties. For example, if your client were to purchase Blackacre upon condition that the liens be cleared off, she would likely deposit the purchase funds into escrow with instructions that the funds not be released to the seller until the liens were cleared off (or that the funds be used to pay off the liens). 
that you relied entirely on the title report. You know less than it seems. You hope the client got title insurance. ${ }^{7}$ You are not alone.

There is too much variability in the many different vesting documents ${ }^{8}$ utilized throughout the country. The United States contains more than 3,000 counties and county equivalents, ${ }^{9}$ and each of them has their own recording system and customs. ${ }^{10}$ Relevant to this Article, many of these jurisdictions utilize different documents in an attempt to accomplish the same goal: to provide evidence of claims upon property. ${ }^{11}$ Unfortunately, this vesting heterogeneity has consequences. ${ }^{12}$

Understanding these consequences is important. As such, Part II examines the history of heterogeneity and how that development has created costs within our system. ${ }^{13}$ Real estate law has transformed over the last 200 years from a local, parochial pursuit to a substantial engine of economic progress throughout the country and across jurisdictional lines. ${ }^{14}$ Disparate documents with varying consequences and effects means that some parties will make mistakes and that some parties will incur substantial costs to gain the local knowledge necessary to avoid such costs. ${ }^{15}$ This is particularly so when one looks at the purposes of the recording system and the extent to which vesting heterogeneity frustrates these purposes by making searching and utilization difficult and risky.

Part III builds upon this understanding by looking at heterogeneity and its attendant cost through the lens of the numerus clausus, a theory that has been utilized to analyze a similar area of real estate law relating to uniformity. ${ }^{16}$ This theory has been propounded by Thomas Merrill and Henry Smith to describe and explain the effective limitation on property

7. Title insurance is generally understood to be indemnification provided by a title insurance company against loss that occurs if title ultimately inferior to what the title company indicated in its issued title policy. See John C. Murray, Title and Survey Issues in Commercial Real Estate Transactions, in UNDERSTANDing THE Sophisticated ReAl Estate Practice 55, 57-58 (Practicing Law Institute ed., 2003). Effectively, however, if your client can pursue you for malpractice, then you may end up indemnifying her for any potential loss. In truth, then, you hope your client has title insurance other than you.

8. See infra note 53 for a detailed explanation of the term "vesting document."

9. See How many counties are there in the United States?, USGS, http://gallery.usgs.gov/audios/124 (last visited July 17, 2012).

10. See Dale A. Whitman, Are We There Yet? The Case for a Uniform Electronic Recording Act, 24 W. NEW ENG. L. REV. 245, 269 (2002).

11. See id. at 260, 266.

12. See infra Part II.B.

13. See generally infra Part II.A.

14. See id. (discussing the evolution of recording systems); see also infra Part II.B (discussing the economic impact associated with the costs of recording, i.e. title searches, recording fees, etc.).

15. See generally id.

16. See Thomas W. Merrill \& Henry E. Smith, Optimal Standardization in the Law of Property: The Numerus Clausus Principle, 110 YALE L.J. 1, 4 (2000), as discussed infra Part III. 
types at common law, ${ }^{17}$ and this Article proposes that the concept (by justifying the law's hostility to new or different types of property in terms of informational burden) is relevant and helpful here. This is particularly so given the theory's firm establishment in the property law canon and given the analogies that can be drawn between property-type heterogeneity and vesting-document heterogeneity and between the informational burdens examined by Merrill and Smith and the heterogeneity costs identified herein. ${ }^{18}$

Accordingly, the recording system, designed with the singular purpose of providing information to interested parties, ${ }^{19}$ should turn upon that same fulcrum of information - that is, the determination of whether heterogeneous documents are permissible should be driven by whether such new documents provide good and helpful information to interested parties and the unique benefit of which exceeds the unique informational costs thereof. This is how the numerus clausus works with respect to property forms, and how it should work here as well: by driving standardization based upon an informational cost-benefit analysis. Having concluded as much, Part IV then demonstrates a potential application and finally proposes a market-based solution whereby this doctrine might be instituted in this realm of property law. ${ }^{20}$

Based on this analysis, this Article concludes that the numerous types of documents, and the variability within those types, should not be present within our recording system. The law should not ignore this type of heterogeneity in vesting documents, and the numerus clausus analysis provides an adequate vehicle for examining variability and determining when to impose uniformity.

\section{VESTING HETEROGENEITY}

Where does this lack of uniformity come from, and what does it mean? As to its vesting heterogeneity, it is a symptom of our property system in general and our recording system in particular. More than most other areas of law, property law is an amalgam of rules and customs that have accrued over time, tracing back to ancient England and carrying with them the weight and baggage of those times. ${ }^{21}$ Our recording system is no exception.

17. See id

18. See generally id.

19. See Carol M. Rose, Crystals and Mud in Property Law, 40 Stan. L. Rev. 577, 577 (1988).

20. See infra Part IV.

21. See Jennifer Dick \& Andrew Chandler, Shifting Sands: The Implementation of Lucas on the Evolution of Takings Law and South Carolina's Application of the Lucas Rule, 37 REAL PROP. PROB. \& 
Its development and history help explain the myriad types of vesting documents that are central thereto. This explanation does not, however, mean that this variability is proficient. The heterogeneity of documents creates real and significant costs - both in terms of actual transaction costs and in terms of mistakes made and errors overlooked. ${ }^{22}$ The result is an inefficient system that does not effectively accomplish its singular purpose: the communication of information. ${ }^{23}$

\section{A. The Rise of Heterogeneity}

The heterogeneity underlying the myriad vesting documents utilized and recorded across the many different jurisdictions is due to a number of factors. The first is the manner in which our recording system has evolved. $^{24}$

The basic goal of property law is to proscribe and define ownership rights in property, ${ }^{25}$ and a basic element of doing this is ensuring that interested parties can reasonably attain information regarding these ownership rights. Without filling this informational role, property law could not function because ownership rights do not exist in a vacuum- they exist vis à vis other people and individuals, and that relationship cannot subsist unless the parties involved know everyone's relative rights. ${ }^{26}$ The recording system takes care of this by incentivizing claimants to record their

TR. J. 637, 690 (2003) ("Hundreds of years of English legal history have refined the law of custom and established it as a background principle of property law adopted by the states.").

22. See infra Part II.B.

23. This is particularly notable, given the high burden placed upon the individualized information seeking inherent in the American recording system. Some other countries use "Torrens," or registration, systems and issue certificates of title, which serve as binding statements of the land's title. See, e.g., Dale A. Whitman, Digital Recording of Real Estate Conveyances, 32 J. MARSHALl L. REv. 227, 232 (1999). The American recording system issues nothing. "In effect, the system says to members of the public, 'We won't tell you who owns a parcel of land, but you are welcome to review all of the recorded documents that are held in our archives, and decide for yourself about the land's ownership."' $I d$. at 228. One can be forgiven for expecting a system that requires reliance upon the pain of failure of title, as our system does, to require and provide clear and efficient information.

24. See generally Chad J. Pomeroy, Ending Surprise Liens on Real Property, 11 Nev. L.J. 139, 143-48 (2011) (discussing the evolution of recording acts in the context of "surprise liens"); John H. Scheid, Down Labyrinthine Ways: Recording Acts Guide for First Year Law Students, 80 U. DET. MERCY L. REV. 91, 92-101 (2002).

25. See Carol M. Rose, Crystals and Mud in Property Law, 40 Stan. L. Rev. 577, 577 (1988) (indicating that property law works when its "rules . . . signal to all of us, in a clear and distinct language, precisely what our obligations are and how we may take care of our interests.").

26. In other words, people "need some means of assuring that they share a common understanding of . . rights." Henry Hansmann \& Reinier Kraakman, Property, Contract, and Verification: The Numerus Clausus Problem and the Divisibility of Rights, 31 J. Legal StUD. 373, 382 (2002). Without that, "parties may mistakenly make inconsistent uses of the asset or underuse the asset" or misallocate their limited resources. Id. 
vesting documents and then making those documents publicly known. ${ }^{27}$ In other words, vesting documents are the currency relied upon by the recording system to tell people what belongs to whom. ${ }^{28}$ As such, the evolution of the recording system itself tells us much about how vesting documents have evolved and why they are so varied.

Initially, under English common law, there was no real recording system. $^{29}$ Few people were mobile or literate, and land was rarely transferred and generally held in the same family throughout generations. ${ }^{30}$ Accordingly, there was little need for centralized information systems detailing ownership information. ${ }^{31}$ When there was need, transfers were effected by witnessed ceremonies, which physically symbolized transfers and theoretically created something — an actual act that occurred and was witnessed - to which third parties could refer in attempting to understand who owned what. ${ }^{32}$ Once the physical ceremony occurred, ownership was transferred, and the prior owner could no longer affect title. ${ }^{33}$ This basic method of transfer acknowledged and institutionalized the "first in time, first in right" concept of ownership, ${ }^{34}$ even though it made it difficult for people to reference due to the lack of any permanent memorial of the transfer.

This evidentiary problem was initially addressed by the Statute of Uses in $1535 .^{35}$ This law was joined a year later by the Statute of Enrollments, which effectively required most real property transfers to be registered with a public official. ${ }^{36}$ This institution of record keeping would have greatly increased the informational access of interested parties to property information, but the Statute of Enrollments was unpopular and largely

27. See 14 Richard R. Powell, Powell on Real Property § 82.01(1)(a) (Michael Allan Wolf ed., 2000) ("Recording acts, by definition, require the public preservation of written documents of title to land, or of other written evidences of certain proprietary interests.").

28. Id.

29. $I d$.

30. $I d$.

31. Id.

32. See Ray E. Sweat, Race, Race-Notice and Notice Statutes: The American Recording System, 3 PROB. \& PROP. 27, 27 (May 1989). Title to real property was transferred by "enfeoffment," a surrender and transfer of ownership rights from the transferor to the transferee. See id. This was accomplished through the livery of seisin, a ceremony involving the transfer of a piece of the ground, a twig, key, or other symbol. See id.

33. Id.

34. Id. at 27 ; Pomeroy, supra note 24 , at $145-48$.

35. Sweat, supra note 32, at 27.

36. See George Lee Flint, Jr. \& Marie Juliet Alfaro, Secured Transactions History: The First Chattel Mortgage Acts in the Anglo-American World, 30 WM. MitcheLL L. REv. 1403, 1433-38 (2004). 
ineffective. ${ }^{37}$ This haphazard state of affairs was largely regularized by the Statute of Frauds, passed in $1677 .{ }^{38}$ It did away with the exceptions that so badly riddled the Statutes of Uses and Enrollments and required written documents to create or transfer real property interests in most situations. ${ }^{39}$

The requirement of a writing was still not sufficient, however, to provide the type of information necessary to regularly and effectively provide to interested parties the information necessary to understand the ownership rights affecting, and touching upon, a piece of property. ${ }^{40}$ The Statute of Frauds did not accomplish this task because vesting documents were physically conveyed to the transferee, along with the land. ${ }^{41}$ There was no central filing or storage system to track the documents that evidenced ownership - title was literally passed as the prior owner would prove up, and transfer, ownership by physically producing the vesting document. ${ }^{42}$ As such, there was still no real way to be sure who owned what. ${ }^{43}$

Recording acts addressed this deficiency by requiring vesting documents to be recorded in order to have validity. ${ }^{44}$ The first modern recording act was adopted by the General Court of the Massachusetts Bay Colony in 1640. ${ }^{45}$ The act permitted unrecorded vesting documents between the parties to a given transaction, but it required a vesting document to be recorded to have validity against uninformed third parties. ${ }^{46}$

37. The registration requirement was easily avoided by transferring a leasehold estate (which did not have to be registered) and then immediately releasing the transferor's reversionary interest to the lessee-transferee. See Sweat, supra note 32, at 27.

38. See Alberto Luis Zuppi, The Parol Evidence Rule: A Comparative Study of the Common Law, the Civil Law Tradition, and Lex Mercatoria, 35 GA. J. INT’L \& COMP. L. 233, 236-37 (2007).

39. See id. at 236-37.

40. See Sweat, supra note 32 , at 27.

41. Id.

42. See id.

43. See Dean Arthur R. Gaudio, Electronic Real Estate Records: A Model for Action, 24 W. NEW ENG. L. REV. 271, 272-74 (2002). Owners rarely possessed a complete record of prior conveyances, and even those who did could not necessarily be trusted to produce all relevant vesting documents. See id. at 272 .

44. See id.; Sweat, supra note 32 , at 27-28.

45. See Sweat, supra note 32, at 27-28; 14 PowELL, supra note 27, § 82.01(1)(b). The practice of recording written documents, practiced as far back as pre-conquest England, began to gain widespread acceptance and usage by colonial times. See John Hanna, The Extension of Public Recordation, 31 Colum. L. REV. 617, 620 (1931). At the time of America's founding, land was shifting from its static role of wealth production to the dynamic role of a commodity to be bought and sold. See Gaudio, supra note 43 , at 272 . This shift was particularly pronounced in the new world, and the first known recordation in America occurred in 1627 at Plymouth Colony. See Sweat, supra note 32, at 27. This shift intensified throughout the industrial revolution, and it is in this context that the colonies began to establish "American" land recording systems. See id. However, recording was not initially either mandatory or uniform. See Hanna, supra, at 619-20.

46. See, e.g., NATHANIEL BRADSTREet SHURTlEFF, RECORDS OF THE GOVERNOR AND COMPANY OF THE MASSACHUSETTS BAY IN NEW ENGLAND: 1642-1649, at 306 (1853). 
Of particular note here, the first act adopted in Massachusetts described the required format of the vesting document. ${ }^{47}$ This makes inherently good sense: if one is interested in providing useful information to a potentially large population of interested third parties via a central repository, it seems reasonable to standardize the information going into and out of that repository. ${ }^{48}$ This institution of mandatory recording and the concomitant, minor steps toward standardization, represented an important change from the prior haphazard system. ${ }^{49}$ Providing at least some type of vesting information in an accessible manner was no longer a matter of local custom or technicality. ${ }^{50}$

This new system was the foundation for the recording statutes of today. ${ }^{51}$ These acts, of course, eventually caught on throughout America, and all fifty states and the District of Columbia now have recording systems based upon these early forebears. ${ }^{52}$ However, neither the early iterations nor the more recent, modern acts are perfectly tailored to their purpose of providing information, particularly given the circumstances of modern commerce and custom. This is so, in part, because of the heterogeneity of the very grist for these systems: the documents that are recorded. ${ }^{53}$

Simply put, these documents are not consistent. Deeds, mortgages, liens, and myriad other vesting documents all look different across jurisdictions, as our system's ad hoc approach to recording has resulted in a

47. Sweat, supra note 32, at 27-28. A valid vesting document had to contain the essential elements of the conveyance, such as the name of the grantor and grantee, a description of the property and estate granted, and the date of the transfer. Id.

48. See infra Part I.B.

49. Sweat, supra note 32 , at 27-28.

50. See id.

51. See Gaudio, supra note 43, at 272-74. As the complexity and breadth of our real estate records and dealings have grown, the manner in which local recorders take and keep information has become more sophisticated. Still, the basic goal of recording is the same: to provide information regarding title to interested parties.

52. See Christopher L. Peterson, Foreclosure, Subprime Mortgage Lending, and the Mortgage Electronic Registration System, 78 U. CIN. L. REV. 1359, 1364 (2010).

53. For purposes of this Article, documents that pass title from one party to another are referred to as "vesting documents." Though this term is often used, it does not appear to be a term of art with a clear, settled definition. However, the meaning adopted herein makes good sense, given the common language definition of the word "vest." See BLACK'S LAW DICTIONARY, supra note 6, at 1083 (defining "to vest" as "to give an immediate, fixed right of present or future enjoyment"). It also appears to be in accord with relevant authority. See, e.g., Sintz v. Stone, 562 So.2d 228, 229 (Ala. 1990) ("A deed [is a] conveyance of realty .....”); Sun Valley v. Burt, 853 P.2d 607, 609 (Idaho 1993) (citing IDAHO CODE ANN. § 55-813 (West 2012)) ("[A] conveyance . . . includes 'every instrument in writing by which an estate or interest in real property is created, alienated, mortgaged, or encumbered, or by which the title to any real property may be affected, except wills."”); Dixon v. Still, 121 A.2d 269, 272 (Md. Ct. App. 1956) (speaking of deeds in the context of passing title). See also, e.g., Mich. COMP. LAWS. ANN. $\S$ 565.1 (West 2012) (stating that, [C]onveyance of lands, . . . may be made by deed . . . ."); OHIO REV. CODE ANN. §5302.171 (West 2012) (referring to deeds or other instruments "vesting title"). 
variety of inconsistent views and requirements as to what can, or must, be recorded. ${ }^{54}$ This can be traced to the ad hoc evolution of recording described above. ${ }^{55}$ For instance, the early Massachusetts experiments with recording involved written summaries of the relevant documents. ${ }^{56}$ This soon evolved into copying the entire document into the public record books, so as to eliminate the risk of mistake or omission. ${ }^{57}$ This sort of evolution is consistent with that of the larger system and encompasses and explains the different types of documents that are utilized in different jurisdictions.

The evolution can also be traced to the manner in which the documents themselves have evolved. Consider, for example, the evolution of transfer deeds. The earliest type of deed was the charter of feoffment. ${ }^{58}$ This deed involved the livery of seisin ceremony described above and passed into obsolescence with the passage of the Statute of Uses, in favor of a bargain and sale deed. ${ }^{59}$ In the more than 300 years since then, different kinds of deeds have come and gone, with the law presently settling on the general warranty deed, the special warranty deed, and the quitclaim deed. ${ }^{60}$ These deeds, however, are not precisely the same and can vary significantly, even within the same category. ${ }^{61}$ As such, even when the evolution of a vesting

54. Consider, for example, a hypothetical party that desires to file a security instrument to secure the performance of a non-monetary obligation with a piece of real property located in Nevada. There is substantial uncertainty, from jurisdiction to jurisdiction, regarding the permissibility of such a "performance deed of trust," which secures something other than a liquidated obligation. The general rule is that a mortgage can generally be given to secure any "contract, duty, or obligation" so long as that contract, duty, or obligation "is capable of being reduced to a monetary value." See 59 C.J.S. Mortgages $\S$ 206; RestateMENT (THIRD) OF PROPERTY: MORTGAGES $§ 1.4$ (2011). This would permit the securing of obligations that are currently unliquidated but will become liquidated in the future and would prohibit securing obligations that are entirely imprecise (for instance, an obligation to "care and love mortgagee for the rest of mortgagor's life."). There is no specific Nevada law on point, but some state statutes do appear to support the general proposition because they indicate that a trust deed can be given "to secure the performance of an obligation or the payment of any debt." See NEv. REv. STAT. § 107.020 (2009) (emphasis added). However, some jurisdictions appear to disagree with this view in that they require an exact, extant debt at the time the security interest is given. See, e.g., Bangerter v. Poulton, 663 P.2d 100, 101 (Utah 1983). This diversity of view on what is permitted will necessarily result in differing documents being adopted and utilized.

55. See Sweat, supra note 32, at 28. There are, of course, broadly applicable rules that apply in all, or most, jurisdictions. See id. Every recording act operates under a "notice," "race notice," or "race" schema, the effect of which is to ensure that all claimants record their interests. See id. But the type and content of what must be recorded has never been systemically regulated.

56. See Whitman, supra note 23, at 234.

57. Id.

58. See DUKEMINIER, supra note 3 , at 585 .

59. See supra note 32 and accompanying text; See DUKEMINIER, supra note 3, at 585.

60. See DUKEMINIER, supra note 3, at 585-86.

61. See id. (discussing the different language that may be contained within deeds and the different forms that might be utilized). 
document narrows itself into a broad type or series of types, there is no true uniformity as to what gets recorded. ${ }^{62}$

This is especially so when considered in the context of the thousands of different jurisdictions and recording systems present throughout the country. ${ }^{63}$ There is no central authority for these thousands of jurisdictions, so there are thousands of rules and norms dictating and defining what is and is not recordable. ${ }^{64}$ In other words, the basic nature of having such a vastly unregulated recording system inevitably instills into the system substantial variability. Of course, the goal of most recording systems is the same, and they generally operate under broadly similar principles. For example, recording generally involves presenting a copy, or an original, of the relevant document to a county recorder, who then time stamps, indexes, and files it. ${ }^{65}$ Most recording systems include two indexes - one that lists grantors alphabetically, and one that lists the grantee. ${ }^{66}$ An interested party - e.g., a potential purchaser or lender - can utilize these indexes in order to determine who owns title. ${ }^{67}$ So long as that generic goal is met, the system seems satisfied.

However, there is great room for inconsistencies within these broad parameters. Most notable here, there is no consistent requirement as to content - the recording office is generally given basic parameters to review, which depend on the jurisdiction, and once those basic elements of a document are fulfilled, the office will record the document. ${ }^{68}$ This makes sense from a broader perspective, as the indexes are at that point

62. See David E. Ewan et al., It's the Message, not the Medium!, 60 Bus. Law. 1487, 1487 (2005) (noting that jurisdictions use various types of deeds that are merely modeled after the system used in the seventeenth century).

63. There are approximately 3,600 counties, cities, or other municipalities that utilize a land recording system. See id. These different recording systems largely rely on "accepting paper documents (deeds or other documents affecting title to real property) for recordation." Id.

64. See id. This fragmentation of administration compounds the existing heterogeneity of recordable documents even more, then, by creating systemic variability based upon individualized definitional and substantive requirements or prohibitions. See Whitman, supra note 23, at 260-61 (discussing the "quirks and idiosyncrasies of individual county records, so commonly found today as a consequence of local conditions and political factors.").

65. See Peterson, supra note 52, at 1365.

66. See id.

67. See id. An interested party wants to know a number of things. First, it wants to know whether the prospective seller has already sold or mortgaged the property. To determine this, it will look for the seller's name in the grantee index to determine who transferred title to the grantee. See id. It will continue tracing back through all grantees until it finds the original source of title and thereby establish a chain of title. See id. Next, the interested party will search the grantor index to ensure that the seller has not sold or otherwise compromised title. See Peterson, supra note 52, at 1365. Finally, the interested party will attempt to find a release for any mortgage that has ever been given on the property, by any past or present owner. See id. At this point, the interested party will have confidence that the seller has clear title. See id.

68. See id. 
theoretically useful - a given office has theoretically filled its basic goal of permitting others to track down all recorded vesting documents. ${ }^{69}$ But each office has done so somewhat differently, creating a system with different documents in different jurisdictions. ${ }^{70}$

For all these reasons, it is easy to see why our recording system functions the way it does in permitting so many different document types. The history of its development, the evolution of recordable documents and deeds, and the basic ad hoc operation of a decentralized recording system have all led to a laissez faire approach to document content. This is "enough," in that it provides the minimum information necessary, but it is not designed to be easy to search or efficient to access and so creates substantial cost. ${ }^{71}$

\section{B. The Cost of Heterogeneity}

One way to measure the cost of the heterogeneity described above is to examine the extent to which it detracts from the underlying purpose of the recording system. In order to do this, one must examine the system and its operation in more detail.

As set forth above, the generic purpose of recording systems is to provide information to interested users. ${ }^{72}$ This is, of course, a basic concern of property law ${ }^{73}$ and is easy to discern with respect to recording systems based on the historical evolution described above, concerned as it is with the development of the commercial potential of real property and the interests of potential purchasers and lenders. ${ }^{74}$ However, a more thorough understanding of this purpose is necessary to understand the true cost of the heterogeneity described above.

This search for purpose begins by examining the incentives created by the basic operation of the typical recording system. Such a system incentivizes parties to record by invalidating unrecorded transfers of real property interests in favor of subsequent transferees. ${ }^{75}$ It is clear that part of the reason for this relatively harsh result is certainty-voiding prior,

69. See infra Part II.B. for a more detailed view of the recording system's goals.

70. See generally Ewan, supra note 62, at 1487; see also Whitman, supra note 23, at 260-61.

71. See, e.g., infra Part II.B.

72. See Rose, supra note 19 and accompanying text.

73. This concern with how to ensure that interested parties have, or can attain, information regarding possessory and ownership rights is at the very heart of what property law does-it proscribes and defines the rights of ownership in property. See Rose, supra note 25, at 577.

74. See supra Part II.A.

75. See Dan S. Schechter, Judicial Lien Creditors Versus Prior Unrecorded Transferees of Real Property: Re-Thinking the Goals of the Recording System and their Consequences, 62 S. CAL. L. REV. 105, 109 (1988). 
unrecorded transfers incentivizes regular recording and so ensures accurate information. ${ }^{76}$ This is not the only reason, however. If it were, then all unrecorded interests would be void, and that is not how the system operates. ${ }^{77}$ An unrecorded transfer is voided only when a qualified, later transferee properly challenges the earlier, unrecorded conveyance. ${ }^{78}$ In other words, the system invalidates too few transfers for certainty to be its sole goal. ${ }^{79}$

On the other hand, another clear goal of recording systems is to discourage fraud. ${ }^{80}$ Without a recording system to impart ownership information, grantors could fraudulently convey the same interest multiple times. ${ }^{81}$ Again, however, the actual operation of the recording system belies this as a stand-alone goal-if it were, the system would likely invalidate fraudulent transfers and no others. ${ }^{82}$ But it does not do that. Instead, it invalidates transfers based upon objective criteria not related to fraud, which certainly results in the voiding of many non-fraudulent transfers. ${ }^{83}$ In other words, the system invalidates too many transfers for fraud to be its sole goal. $^{84}$

Thus, looking at either the goal of certainty or the goal of fraud deterrence is unhelpful. Looking at the two goals together, however, is fruitful. ${ }^{85}$ Again, the system invalidates too few unrecorded transfers for certainty to be the sole goal, but too many for fraud deterrence to be the sole goal. So the question becomes why does the system leave some transfers intact and invalidate others? The answer appears to focus primarily upon the potential injury and the actual knowledge of the party that would benefit from the avoidance of a prior interest. In particular, transferees must exchange value for their interest (that is, have a real, potential injury) and be

76. See, e.g., Douglas G. Baird \& Thomas H. Jackson, Possession and Ownership: An Examination of the Scope of Article 9, 35 STAN. L. REV. 175, 183 (1983).

77. See Schechter, supra note 75, at 110.

78. Id. An unrecorded transfer must be challenged, and it must be challenged by a qualified transferee. See id. This deviation from uniformly voiding all unrecorded transfers necessarily results in some uncertainty.

79. Id.

80. See SHURTLEFF, supra note 46, at 306. An explicit goal of early recording laws was to address the problem of fraudulent conveyances. See Mark DeWolfe Howe, The Recording of Deeds in the Colony of Massachusetts Bay, 28 B.U. L. REv. 1, 3 (1948). In fact, preventing fraudulent conveyances might have been the primary goal of these initial acts. Certain amendments to the Massachusetts statute indicate, for example, that recording was required only where a grantor retained possession of the property following the transfer of an interest. See id. This focus evinces a preoccupation with circumstances that might confuse third parties and other types of potentially fraudulent arrangements.

81. See Schechter, supra note 75 , at $110-11$.

82. See id. at 111.

83. See id.

84. Id.

85. See id. at $113-20$. 
ignorant of the prior interest (that is, not be able to reasonably avoid the injury) in order to trigger the recording system's avoidance powers. ${ }^{86}$ This has been termed a "cost avoidance" rationale and explains, in theoretical and more nuanced terms, the evolution of the recording system that can be discerned from an examination of the history discussed above: the goal of the recording system is to permit interested commercial actors (i.e., those exchanging value for a property interest) who need ownership information (i.e., those who do not already possess such information) to obtain that information in a reliable manner. ${ }^{8}$

So, returning to the issue at hand, does countenancing and accepting a very wide range of potentially recordable documents ${ }^{88}$ accomplish this task in an acceptable way? From the perspective of whether heterogeneity negatively affects the purpose of the recording system - the question set forth at the beginning of this section- the answer is "no." 89 Heterogeneity is not acceptable because it makes organization and searching difficult and expensive and so effectively restricts the access sought by interested commercial actors..$^{90}$

86. See Schechter, supra note 75, at 113-20 (discussing two hypothetical transfers, one to a donee and one to a purchaser for less than market value and inducing the purpose behind the system's negative treatment of the former and positive treatment of the latter). Injury, then is required, though relative harm is not part of the calculus. See, e.g., Cunningham v. Norwegian Lutheran Church of Am., 184 P.2d 834, 840 (Wash. 1947) (upholding a bona fide purchase for value even though buyer purchased for only $\$ 100$ real estate valued at $\$ 1,500)$.

87. See Schechter, supra note 75 , at 119 ("We may label the preceding descriptive theory as the 'cost avoidance' rationale, because the system (1) requires that the subsequent transferee be likely to suffer costs in the absence of protection; and (2) requires that the parties take action to avoid those costs."). The system is simple; it does not attempt to balance potential injury or relative costs. See id. This may be a form of rough justice, eschewing perfect the expense of balancing in favor of a simple and easily understood system. See id. This, again, comports with a system focused primarily on the provision of information.

88. Recall, again, just how much variability is inherent in the recording system. See Ewan, supra note 62 , at 1487 . The heterogeneity described herein is, as we have seen, an organic element of the system, existing as it does due to the natural, historical evolution of the system. But this bred-in variability is even worse than that, as it is amplified across the more than three thousand jurisdictions present in the United States. See id. In other words, the raw number of systems involved materially affects every aspect of the system.

89. Another way of stating this is to ask whether heterogeneity is "efficient" under an economic analysis of the law. Broadly put, economic analysis of the law is an approach to legal analysis that applies microeconomic theories, such as cost-benefit analyses, to legal issues. See STEPHEN M. BAINBRIDGE, CORPORATION LAW AND ECONOMICS 18-19 (2002). From a positive perspective, economic analysis can be utilized to explain the development and current state of the law regarding the heterogeneity of vesting documents. See Richard A. Posner, The Economic Approach to Law, 53 TEX. L. Rev. 757, 768 (1975). As such, the question here would be whether the current system of permitting the recording of differing types of vesting documents is economically justifiable. Any decrease in cost would make the dissemination of information more economical and so more efficient.

90. See supra note 87 and accompanying text for an explanation of the intended user of a recording system, as reflected by its actual operation. 
This point can be made another way by examining a salient area of research from a different academic field. Database theory research arises in the context of computer science and focuses on the organization and structure of database information. ${ }^{91}$ The title records created and collected by the recording systems (that is, necessarily created and filed by individuals who do not want their property interests to be voided because they have not properly recorded) constitute, in effect, a large, shared data bank. And there has been significant research into the manner in which such data banks are organized and the manner in which they can and should be accessed and utilized. ${ }^{92}$

In particular, computer scientists have studied and compared different database organizational models that are relevant here. The first model of note is the relational view (or model) of data. ${ }^{93}$ Under this first database model, a compound piece of information is broken into component pieces and organized into tables with structured columns (fields) and rows (records). ${ }^{94}$ The second model of note is the "flat" view (or model) of data. Under this second database model, a compound piece of information is not broken into component pieces, but rather stored in a single retrieval space. ${ }^{95}$

91. See, e.g., Mohammad Chulam Ali, Evolution of Database Emerging to Sybase Adaptive Server Enterprise and Ensuring Better Server Performance Tuning and Query Optimization, 35 INT'L J. COMPUTER APPLICATIONS 37, 38-39 (2011).

92. See generally E.F. Codd, A Relational Model of Data for Large Shared Data Banks, 13 COMMUNICATIONS ACM 377 (June 1970) ("This paper is concerned with the application of elementary relation theory to systems which provide shared access to large banks of formatted data."). Accessing large pools of data is something that we tend to take for granted. Think, for example, of the last time you utilized Westlaw or LexisNexis to do legal research. Or think of the last time you used Google or Bing to search for anything on the internet. In today's world, there is an enormous amount of information collected and available electronically - that is, there is a huge shared data bank available in various formats, including, but not limited to, the internet itself - but this information is only useful to the extent that you can access it efficiently and effectively (hence the popularity and success of effective "search engines").

93. See id. This paper is significant in that it sets forth, for the first time, the concept of a relational database, which is now the standard. See Chulam Ali, supra note 91, at 37-40. Prior to Mr. Codd's work, databases tended to be "flat." Id.

94. See Codd, supra note 92, at 379-82.

95. See id. An example may be useful. In a traditional, "flat" database, information is stored in a distinct, comprehensive text file (i.e., File \#1: Jonathan Airy, 01/01/2010, PN 12345, Mortgage Interest; File \#2: Rebecca Bender, 06/01/2010, PN 12345, Mechanics Lien; ad finitum). This organizational format makes it difficult to search for specific information or to isolate relevant bits of information or data because one has to search each and every text file to gather the necessary information. See id. The relational model, on the other hand, is far more flexible and efficient, because it utilizes a table to store information, breaking the component pieces of information into separate bits. See Chulam Ali, supra note 91, at 38-39. Standard fields and records are put into a table format, such as the following:

\begin{tabular}{|l|l|l|l|}
\hline Name & Date & Parcel Number & Type of Interest \\
\hline Jonathan Airy & $01 / 01 / 2010$ & PN 12345 & Mortgage Interest \\
\hline Rebecca Bender & $06 / 01 / 2010$ & PN 12345 & Mechanics Lien \\
\hline
\end{tabular}


The relational model is widely considered to be more efficient than, and superior to, the flat model because it is easier and more efficient to organize and sort information. ${ }^{96}$

These differing models are relevant here in that standardized documents permit the construction of a relational model, whereas non-standardized documents force one to use a flat model. This is so because the relational database organization requires that the initial compound piece of information be structured in a standardized manner. ${ }^{97}$ It is simply not possible to create tables that can be consistently populated and thereafter systemically searched by field unless they consist of standardized, structured input. $^{98}$ As such, homogeneity of vesting documents would permit the use of a relational model, whereas heterogeneity of vesting documents ensures the use of a flat model. As the flat model is more difficult to organize and access, it will be more costly to search for information and access the information found (which is, ultimately, the goal of the recording system).

An example may help to make the point. Assume that Jurisdiction A requires all deeds of trust to contain only the following information: parcel number, name of trustor, name of beneficiary, name of trustee, and amount secured. Each time a deed of trust (a compound piece of information) is recorded, it can be broken into the component pieces of information referenced above and placed into a table. In that manner, any interested party could quickly and easily search for deed of trust encumbrances by parcel number, by beneficiary (lender), by trustor, or by any other singular piece of data required. Now assume that Jurisdiction A has no standardized requirements. Perhaps it requires some information, but does not limit other information, or perhaps it does not require anything in particular beyond the name of the grantor and the legal description. ${ }^{99}$ Each time a deed of trust is recorded, the county recorder will simply take the document (which may be one page or thousands of pages) and record it against the relevant parcel. The only way, then, for an interested party to search is by legal description

This type of table organization permits one to quickly and easily compare isolated pieces of information, across all relevant fields because the information is organized, and searchers can focus on the relevant column or row. See Codd, supra note 92 , at 379.

96. See id.

97. See Chulam Ali, supra note 91, at 38-39.

98. This is self-evident from the nature of the organization. If the information is not structured by type (i.e., the same fields), there will be no table. Instead, there will merely be a series of unique information compilations, as in the traditional "flat" database model. See Codd, supra note 92, at 37982.

99. It is not conceivable that a recording system would not require a parcel number or legal description, as the document at issue must be recorded against some piece of real property. 
or grantor-the system is inflexible and may be confusing, depending on how many different documents are recorded and how much information each such document contains (or does not contain). Moreover, even once it is found, the document is likely to be difficult to access and understand because it is not standardized. ${ }^{100}$

In other words, our recording system is one, large, outdated database. As such, we are left with a structure that is, by its very nature, costly and inefficient. It exists to make information available to the right parties at the right time, but it does not perform this function well. It does work, in a limited way, in that it harnesses some perceptible and retrievable information into a format that provides some level of notice. ${ }^{101}$ The system merely ensures a baseline level of informational access, without regard to cost or effectiveness. It is not surprising, then, that there is little efficiency and that, for the all the reasons set forth above, heterogeneity makes it more difficult and more costly for interested parties to retrieve and access the type of information the system is designed to propagate. ${ }^{102}$ This relationship between variability and cost is not unique to vesting documents. Indeed,

100. This difficulty might arise because individuals, having been given free reign, may have created dense and difficult documents. However, even if the documents are not difficult (or not more difficult than a hypothetically uniform jurisdiction), it will necessarily take more time (i.e., create more cost) to review because of the variability involved. Any lack of standardization will require either an entirely unique review of each document or a relatively more careful review of each document than what would be required if the documents were standardized (even if that given document is comparatively simple), thus building in an inevitable "review premium."

101. Indeed, the system functions by way of title attorneys and insurers carefully searching the records to find all information that the potentially interested party will be deemed to possess by the recording system. See John W. Fisher, II, The Scope of Title Examinations in West Virginia Revisited, 111 W. VA. L. REV. 641, 642 (2009). This is a difficult job, by its nature - the title examiner must search all relevant records for the appropriate time frames and recognize the legal significance of the information discovered. See id.

102. Indeed, it is at least partially due to this reason that the title industry is a multi-billion dollar industry, generating $\$ 8.7$ billion dollars in premiums in 2010 alone. See Press Release, A.M. Best Co., A.M. Best Special Report: Despite Economic Turbulence, Title Industry Outlook Remains Stable (Oct. 10, 2011), http://www3.ambest.com/Frames/Frameserver.asp?site=press $\&$ Tab $=1 \&$ altsrc $=2 \&$ RefNum $=$ 65494655775346556649 . This cost, then, is very real and very significant to the public at large. There is some indication that modern actors have endeavored to address this by way of the establishment and operation of private "title plants." See Whitman, supra note 23, at 227. A title plant contains duplicates of public records but indexes them by land parcel rather than by name and are a clear attempt to counter the plain fact that a system developed for an agrarian society with a small population has been forced to expand to serve thousands of jurisdictions with millions of residents and hundreds of thousands of land parcels. See id. While these title plants may help with some issues, they do not, and cannot, however, address the basic problem raised herein: the lack of structured information with which they deal. Regardless of who maintains the information, or in what manner they do so, this underlying heterogeneity will continue to ensure that it is difficult and costly to perceive information. 
there is well-established and well-studied authority that has examined an analogous situation and has similarly found heterogeneity is costly. ${ }^{103}$

\section{THE NUMERUS ClAUSUS}

Hostility toward that which is "different," based upon the costs inherent in heterogeneity, is not new. Thomas Merrill and Henry Smith have previously propounded what they call the numerus clausus theory, which posits an explanation as to why the law and the courts have traditionally been hostile to new and different types of property forms and have eschewed heterogeneity in favor of uniformity. ${ }^{104}$ According to Merrill and Smith, the reason for this hostility is the high cost of "newness," the acceptance and permission of which causes others to spend time and energy discerning parties' relative rights. ${ }^{105}$ This cost, arising from the informational burdens of new property types, is highly analogous to the vesting heterogeneity costs identified above. As such, it is useful here to examine in greater detail both the theory itself and the costs identified by Merrill and Smith, upon which the theory turns.

\section{A. The Theory}

The numerus clausus describes the manner in which property law restricts parties' discretion to shape or customize their ownership interests according to their own desire. ${ }^{106}$ People cannot create new or different types of property to fit new and different circumstances or situations - property law recognizes only a limited number of basic property forms or types and refuses to allow parties to stray from these set categories or "boxes.", This rule is explicitly accepted in civil law countries, which acknowledge the concept and refer to it by name (the "numerus clausus,"

103. See, e.g., Merrill \& Smith, supra note 16, at 35-38 (analogizing the "inventory of property rights" with the "lexicon of a language" and the risks of standardization which can result in frustrating purposes and raising costs).

104. See Merrill \& Smith, supra note 16, at 3-5. See generally Henry E. Smith, Community and Custom in Property, 10 TheORETICAL InQuiRIEs L. 5, 34-36 (2009); Thomas W. Merrill \& Henry E. Smith, What Happened to Property in Law and Economics, 111 YALE L.J. 357, 385-88 (2001).

105. See Merrill \& Smith, supra note 16, at 5-6.

106. See id. at 3 . This is in contrast to contract law, which is not generally limited as to type or duration. See id. There may be some narrow limits based on public policy, but, once a promise meets the legal elements of contract law, the law will honor almost any contract, no matter how unusual the promise, the consideration, or the length and nature of the contractual relationship. See id.

107. See id. (citing Keppell v. Bailey, (1834) 39 Eng. Rep. 1042 (Ch.) 1049 ("[I]ncidents of a novel kind [cannot] be devised and attached to property at the fancy or caprice of any owner."). Merrill and Smith latch on to the phraseology in this case to describe their thesis that the law will not permit "fancies" based upon the numerus clausus. See Merrill \& Smith, supra note 16, at 25. 
which means "the number is closed"). ${ }^{108}$ The concept is not explicitly acknowledged or labeled in our common law, but it can be seen here. ${ }^{109}$

Historically, the courts have followed and enforced the numerus clausus by either striking down parties' attempts to create new interests or recasting any attempted "fancy" as something else that fits within the law's traditional oeuvre. ${ }^{10}$ This is apparent with respect to all property types now familiar to us.

Estates in land are the most obvious example. There are five types of possessory estates (the fee simple absolute, the defeasible fee simple, the fee tail, the life estate, and the lease) and a similar number of corresponding future interests (reversions, termination powers, remainders, and executory interests). ${ }^{111}$ The courts rarely vary from this "formalistic, box-like structure." $" 12$ Regardless of whether the parties want to create a new type of property interest, courts will honor the numerus clausus concept by refusing to honor that intent and expand the type of interests allowed. ${ }^{113}$ This strict

108. See id. at 5 .

109. See id. at 4 (citing John Henry Merryman, Policy, Autonomy, and the Numerus Clausus in Italian and American Property Law, 12 AM. J. CoMP. L. 224 (1963)); Bernard Rudden, Economic Theory v. Property Law: The Numerus Clausus Problem, in OXFORD ESSAYS IN JURISPRUDENCE: THIRD SERIES 239, 240 (John Eekelaar \& John Bell eds., 1987).

110. See Merrill \& Smith, supra note 16, at 11 (describing the numerus clausus as a "norm of judicial self-governance," functioning like a canon of interpretation applicable to common-law decision making or like a "strong default rule in the interpretation of property rights."). The example given by Merrill and Smith serves to make the point: landlord-tenant law is affected by the numerus clausus insofar as leases are limited to four types: the term of years lease, the periodic tenancy, the tenancy at will, and the tenancy at sufferance. See id. And the courts will not gladly permit any deviation therefrom. A lease "for the duration of the war," for instance, would almost certainly not be enforced according to its terms. Seeking to place such a lease within one of the four recognized "boxes" of ownership, a court would probably shoehorn the lease into category of periodic tenancy or a tenancy at will. See id. at 11-12. But see Garner v. Gerrish, 473 N.E.2d 223, 225 (N.Y. Ct. App. 1984) (characterizing an interest as a "life tenancy terminable at the will of the tenant."). There is no such thing as a lifetime lease at common law, so such an interest would fall outside the recognized categories and so constitute a departure from the numerus clausus. See Merrill \& Smith, supra note 16, at 22-23 (discussing Garner, 473 N.E.2d 223). Still, the point is well taken, with significant supporting authority. See id. at 3-4 (citing 1 Richard R. POWEll, Powell on Real Property § 11.01, at 11-12 (Patrick J. Rohan ed., 1999); Charles Donahue, Jr. et al., Cases and Materials on Property: An Introduction to the CONCEPT AND THE INSTITUTION 457 (3d ed. 1993); JESSE DUKEMINIER \& JAMES E. KRIER, PROPERTY 204 (4th ed. 1998); LeWIS M. SimES \& ALLAN F. SMith, THE LAW OF FUTURE INTERESTS § 61, at 45-46 (2d ed. 1956)). These authorities all refer, to some extent, to property interests as being a closed or standardized system. Merrill and Smith believe that courts and scholars generally honor this conception of property despite their protestations to the contrary: "They treat previously-recognized forms of property as a closed list that can be modified only by the legislature." Merrill \& Smith, supra note 16, at 1011 .

111. See id. at 12-13; see also DUKEMINIER, supra note 3, at 183-316.

112. See Merrill \& Smith, supra note 16, at 13 (quoting CURTIS J. BERGER \& JOAN C. WILLIAMS, PROPERTY: LAND OWNERSHIP AND USE 211 (4th ed. 1997)).

113. See, e.g., Stuehm v. Mikulski, 297 N.W. 595, 603 (Neb. 1941) (Carter, J., concurring) ("It is essential that titles and estates in land be definite and certain. It is not a field in which the court should undertake to establish that it is liberal and modernistic in keeping pace with changing conditions. The 
approach extends to all types of property. Concurrent interests, ${ }^{114}$ nonpossessory interests, ${ }^{115}$ personal property, ${ }^{116}$ and intellectual property ${ }^{117}$ all receive the same treatment-even though the courts never use the term "numerus clausus," they steadfastly follow its precepts and deny parties the right to create new interests of their own choosing.

Interestingly, one "property type" not mentioned by Merrill and Smith is that of a secured lien. The creditor-recipient of a security interest is the holder of a property interest, albeit one that does not fit into the schema identified above. ${ }^{119}$ And, similar to the categories examined above, these

creation of hybrid estates unknown to the common law is to be deplored."). This is not to say that property cannot be customized in other ways. So long as the customization falls within one of the accepted categories of property in that it does not stray outside acknowledged, basic legal dimensions, then the courts will accept it. See Merrill \& Smith, supra note 16, at 14.

114. With respect to concurrent interests, American common law recognizes a very basic catalogue of property: joint tenancy; marital property; trusts; and condominiums, cooperatives, and timeshares. See id. at 15 (citing 5 Powell, supra note 110, § 40.500, at 40-43; 7 RICHARD R. POWELL, POWELL ON REAL PROPERTY § 49.01, at 49-52 (Michael Allan Wolf ed., 2001)). The failure of the judiciary to respond to changing social norms affecting women's rights and commercial pressure regarding cooperative housing (leaving the legislature to do so by, for example, abolishing dower and curtesy and passing condominium and time-share statutes) speaks to the judiciary's self-imposed reluctance. See id.

115. The same judicial reluctance is evident with respect to nonpossessory interests. Easements, covenants, equitable servitudes, and profits have also been remarkably stable and unchanged by the courts. See id. at 16-17. Equitable servitudes are themselves an exception, as they were created by the judiciary, but that was more than 160 years ago and has been effectively limited in both scope and application. See id. (citing Tulk v. Moxhay, (1848) 41 Eng. Rep. 1143 (Ch.) 1143).

116. Judicial treatment of personal property has been, if anything, even more restrictive than that of the other property interests discussed herein. There is little case law to support the idea that the ownership of personal property can be divided in any significant manner, and almost all attempts to create nuanced property interests in personal property take place in the context of trust law. Merrill \& Smith, supra note 16 , at $17-18$.

117. Finally, intellectual property also shows the effects of the numerus clausus. Historically, there has been no real protection for creative property outside the legislative dictates of patent, copyright, trademark, and trade secret. See generally DUKEMINIER, supra note 3, at 56-96. This has eroded somewhat over time, with the common law development of the "hot news" doctrine and the right of publicity, but these developments have not been so intrusive, or so significant, as to materially undermine the apparent role of the numerus clausus in property law. See Merrill \& Smith, supra note 16, at 19-20 (discussing Int'1 News Serv. v. Associated Press, 248 U.S. 215, 245 (1918)); see also White v. Samsung Elec. Am., Inc., 989 F.2d 1512, 512 (9th Cir. 1992).

118. See id. at 5-6.

The principle that property forms are fixed and limited in number represents an extremely important qualification to the principle of freedom of contract . . . A willing buyer and a willing seller can create an infinite variety of enforceable contracts for the exchange of recognized property rights, and can describe these property rights along a multitude of physical dimensions and prices. But common-law courts will not enforce an agreement to create a new type of property right.

Id.

119. See, e.g., Christopher L. Peterson, Two Faces: Demystifying the Mortgage Electronic Registration System's Land Title Theory, 53 WM. \& MARY L. REV. 111, 139-40 (identifying a secured lien as 
lienhold interests generally fit within an easily identifiable "box." Here, almost all secured lien interests in real property are either a mortgagor interest or a beneficiary interest arising from a deed of trust. ${ }^{120}$ Similarly, almost all secured lien interests in personal property arise within the context of the Uniform Commercial Code ("UCC") and so fit within the relatively narrow bands of creativity permitted therein. ${ }^{121}$ In other words, even if one broadens the scope of potential property interests at issue beyond what Merrill and Smith have examined, our system still honors the closed system of the numerus clausus. ${ }^{122}$ And, as mentioned above, it does so without

a property interest); Peter Soskin, Protecting Title in Continental Europe and the United StatesRestriction of a Market, 7 HASTINGS BUS. L.J. 411, 413 (2011) (identifying a secured lien as a property interest). Of course, the phrase "property interest" can be interpreted widely in a number of different contexts. See, e.g., O’Bannon v. Town Court Nursing Ctr., 447 U.S. 773, 781 n.12 (1980) (discussing shifting views of the definition of "property interest"). However, it seems reasonable to define a property interest, in the context of our discussion of the numerus clausus, which speaks broadly to all property types, as something approximating the following: "a legal right of one person enforceable against another person or class of persons with respect to the possession, enjoyment and/or alienation of a thing." Jeanne L. Schroeder, A Repo Opera: How Criimi Mae got Repos Backward, 76 AM. BANKR. L.J. 565, 580 (2002). This makes sense in that the numerus clausus applies in the context of real and personal property and how the law defines the types of ownership cognizable therein. It also makes sense in that it focuses on the in rem nature of property law, which is key to understanding the basis for the numerus clausus and how that applies to heterogeneous vesting documents. See infra Part II.B.

120. See, e.g., GeORge Gleason Bogert et Al., The LaW of Trusts and TrusteEs $§ 593$ (rev. $2 \mathrm{~d}$ ed. Supp. 2011). But see supra note 54. The "performance deed of trust" contemplated therein may be construed as giving rise to a new type of interest and hence undermining the numerus clausus concept. On the other hand, as set forth in supra note 54, such an interest would likely be permitted only to the extent that it met the rules applicable to historical lienhold interests, thereby effectively mimicking the substantive elements thereof. This sort of "soft" pressure is precisely the manner in which our common law courts have enforced the numerus clausus, as is discussed in greater detail below.

121. See, e.g., 8 William D. HaWkland ET AL., Uniform Commercial Code SERIES, Article 9. Secured Transactions; Sales of Accounts and Chattel Paper, § 9-102:1 (West 2011) (describing the broad scope of Article 9 as it relates to personal property).

122. One potentially significant counter example, however, arises in the context of the lienhold interests not examined by Merrill and Smith and relates to the relatively recent advent of the Mortgage Electronic Registration System ("MERS"). See generally Pomeroy, supra note 24, at 162-64. MERS is a private database that tracks ownership and assignments of mortgages. See Beau Phillips, MERS: The Mortgage Electronic Registration System, 63 CONSUMER Fin. L.Q. REP. 262, 263 (2009). Beginning approximately 20 years ago, the mortgage industry began to evolve in numerous ways. See id. at 262 . One aspect of this was to separate the servicing of loans and the ownership of loans from each other and to further separate the ownership of loans from the holder of the underlying note. See id. This latter innovation is often associated with dividing the ownership of a loan, or a bundle of multiple loans, among various owners (often occurring in connection with the packaging of mortgages into mortgagebacked securities). In such a situation, none of the owners of the underlying note ever hold the note, have any real contact with the buyer (and often the originator), or even know who the borrower, or what the collateral, is. See, e.g., Kurt Eggert, Held up in Due Course: Predatory Lending, Securitization, and the Holder in Due Course Doctrine, 35 CREIGHTON L. REV. 503, 546-48 (2002). Traditionally, separating ownership from form in this manner would cause difficulty because the parties would have to prepare and record an assignment of the security instrument to be recorded in the appropriate recording office. See Mortgages: MERS and Foreclosures, 39 REAL EST. L. REP. 1, 1-2 (Oct. 2009). This was cumbersome, costly, and often caused confusion and chain of title problems. See id. MERS addressed these problems by streamlining and simplifying the process. See Phillips, supra, at 263. It eliminated 
explicitly recognizing or explaining why-that is, without even acknowledging the numerus clausus principle.

It is, then, something of a "stealth doctrine."124 Merrill and Smith have identified a relatively unknown decision that they tepidly endorse as a "leading case," " but its very lack of impact speaks to the subtle standing of the numerus clausus in the common law. In Johnson v. Whiton, ${ }^{126}$ Royal Whiton devised land to his granddaughter "and her heirs on her father's side." 127 The court construed this devise as an attempt to create a new type of property interest (i.e., a new type of estate) and specifically disapproved of the attempt. ${ }^{128}$ Instead, it ruled, Royal's granddaughter received a fee simple absolute. ${ }^{129}$

Merrill and Smith see this as a seminal case of sorts, both because it has the hallmarks of a case that one might think other authorities would be attracted to, ${ }^{130}$ and because it so nicely fits their description and view of the numerus clausus as a widely controlling, but subtle and unnamed, rule of

the need for a new assignment each time a secured obligation was sold, traded, or securitized by creating a privatized, internal system that tracked ownership information for its members. See id. MERS members, in exchange for an annual fee, have the ability to appoint MERS as their agent with respect to registered mortgages. Id. After they have done so, MERS is the mortgagee of record, and members can then trade these registered mortgages among themselves via MERS internal records and without recording any assignments. Id. MERS remains the nominee for the owner, whoever it is, and regardless of how often the mortgage is pooled, dissected, or sold. Id. The recorded mortgage is never assigned on public records but retains its priority: under common law, as a nominee, or under the Uniform Commercial Code, as a transferee or as a holder of a note indorsed in blank, MERS has standing to bring a foreclosure on behalf of the owner or owners of a note in default. See, e.g., Mortg. Elec. Registration Sys., Inc. v. Azize, 965 So. 2d 151, 154 (Fla. Dist. Ct. App. 2007). The process is without cost and remains unknown outside the MERS system. The relevant question this raises here is whether a "MERS mortgage" is, in fact, a new and different type of property interest. As discussed and described above, property interests are types of ownership that can be consistently categorized based upon identifiable legal attributes such as the rights and obligations of owners and duration. See Sweat, supra note 32 and accompanying text. By lessening the obligations of owners of secured liabilities and increasing their rights to assign and transfer, then, MERS arguably creates a new property type. This would undermine Merrill and Smith's support for the numerus clausus, particularly given the recent and vast expansion of MERS. The system has grown exponentially since its creation, with MERS claiming that it is now the nominal mortgagee on up to two-thirds of new residential loans in the country. See Phillips, supra, at 264.

123. This is so, even in Louisiana, a state often more heavily influenced by the ideas and concepts behind French civil law than those behind English common law. See, e.g., Anders Walker, The New Common Law: Courts, Culture, and the Localization of the Model Penal Code, 62 HASTINGS L.J. 1633, 1638 (2011).

124. See Merrill \& Smith, supra note 16 , at 20-23.

125. See id. at 21 (discussing Johnson v. Whiton, 34 N.E. 542 (Mass. 1893)).

126. 34 N.E. 542.

127. See Johnson, 34 N.E. at 542 .

128. See id.

129. See id.

130. See Merrill \& Smith, supra note 16, at 20-21 (footnotes omitted) ("The facts are simple. The opinion . . . was authored by Oliver Wendell Holmes, Jr., one of America's most celebrated jurists and an authority on the history of the common law. The opinion's reasoning ... is tightly compressed, yet advanced with great self-assurance.”). 
law. ${ }^{131}$ However, even they acknowledge that the case has not attracted much attention. ${ }^{132}$ It is not widely cited in either case law or by treatises, and, to the extent that it is referred to, it is primarily in connection with other issues. ${ }^{133}$

In sum, the courts may not cite the principle, and historical treatises may not recognize its wide application, but there is significant reason to believe that the concept is alive and important, undergirding a large swath of American jurisprudence relating to the very nature of property. ${ }^{134}$ The reasons for this are both interesting and relevant to our discussion of the costs associated with heterogeneous vesting documents.

\section{B. Analogous Costs}

So what explains the existence and long-time application of the numerus clausus in both our legal system and in other legal systems? According to Merrill and Smith, this stems not from a concern for

131. See id.

132. See id. at $20-23$.

133. See id.

134. Id. at 21-22. Merrill and Smith do, however, acknowledge the potential that their view of a monolithic numerus clausus may have some weaknesses, primarily by citing and discussing Garner, 473 N.E.2d 223. See id. at 11-12. Therein, the case confronted a document purporting to grant a lease of property for the life of the tenant. This would violate the numerus clausus, as there is no "lease for life" under our classic system of estates. The court ambiguously countenanced the interest, though it may have merely been shoehorning the parties' intent into a life tenancy interest. See Merrill \& Smith, supra note 16, at 11-12. Partially, then, the extent to which adoption of "new" or "different" interests can be seen as undermining the concept of the numerus clausus depends on the extent to which a decision can be seen as actually creating a "new" or "different" interest; that is, the interest ultimately countenanced may, in fact, be a traditional interest with a minor variation or merely a different name. See, e.g., supra note 54. That note discusses the potential creation of a "performance deed of trust," which would constitute a new and different type of vesting instrument, precisely the sort of thing this paper is arguing against. Posit, however, the extent to which a vesting instrument, in fact, affects the underlying nature of the interest at issue. Is a performance deed of trust, of the type discussed above, simply a new and different type of document that describes a well understood type of ownership interest (a lender's secured interest) or is it, in fact, a different type of interest with different sorts of legal attributes (i.e., it can blossom into possession only upon failure of action, not upon failure of monetary payment, which difference is akin to the difference between a remedy for damages and a remedy for specific performance, a well-recognized distinction under the law)? And, if it is indeed a new and different type of interest, then is there not a potential argument that any different type of vesting document creates a somewhat different legal interest? This may be a subtle, but substantial, hole in the concept of the numerus clausus. More likely, though, as foreshadowed herein, the answer is that it really all depends upon how finely one defines "property interest." If any particularity or difference is substantial enough to create a different "type," then it may be that the heterogeneity discussed herein has the potential to undermine the idea that the numerus clausus is widely honored. If, however, one defines "type" as a subset with the same "basic legal dimensions, such as duration, powers of alienation, rights of inheritance, and so forth," then the numerus clausus still holds, as a difference in a vesting document likely does not strike so deeply into what is actually conveyed. See Merrill \& Smith, supra note 16, at 14. 
marketability ${ }^{135}$ but from a concern about informational burdens and costs. ${ }^{136}$ The meaning of this supposition is examined below, followed by a comparison of such costs to the vesting heterogeneity costs identified above. $^{137}$

\section{Informational Burdens Under the Numerus Clausus}

Merrill and Smith argue that the numerus clausus is so deeply ingrained in our jurisprudence because it prevents costs. ${ }^{138}$ Property law focuses on the thing and the rights flowing from that thing, and third parties have to expend time and resources to learn the attributes of these rights. ${ }^{139}$ Unusual property rights increase the cost of doing this, so the numerus clausus effectively blocks unusual property rights in order to decrease costs. ${ }^{140}$

Because it focuses on the corporeal thing itself, this theory of cost can be said to flow from the in rem (as opposed to the in personam) nature of property. ${ }^{141}$ This is inherent in Blackstone's famous definition of property: "that sole and despotic dominion which one man claims and exercises over the external things of the world, in total exclusion of the right of any other individual in the universe." ${ }^{, 142}$ This view of property rights focuses upon the thing itself: rights are defined with respect to an actual, concrete thing that is possessed or "owned" (as opposed to being defined with respect to the actors or individuals involved). ${ }^{143}$ This means that property effectively

135. See id. at 24-25. Therein, Merrill and Smith acknowledge that American cases that implicitly follow the numerus clausus do so out of a concern about restraints on alienation. Such restraints would arise from an excessive fragmentation of property rights that would create an open-ended population of potential claimants and, hence, large cost barriers to exchanges of property. See id. They ultimately reject this justification, though, noting that our current system of estates nicely accommodates a desire to create confusing future interests with large classes of potential claimants. See id. But see Michael A. Heller, The Boundaries of Private Property, 108 YALE L.J. 1163, 1176-78 (1999) (disagreeing with Merrill and Smith by suggesting that the purpose of the numerus clausus is to promote the easy transferability of property).

136. See Merrill \& Smtih, supra note 16 , at $24-42$.

137. See infra Part III.B.1 \& III.B.2.

138. See generally Pomeroy, supra note 24, at 174-76.

139. See, e.g., infra note 151 and accompanying text.

140. See Merrill \& Smith, supra note 16 , at 8 . The numerus clausus, then, effectively presents a closed set of options to lawyers and others seeking to create property rights, and "[t]he chances of persuading a court to create a new type of property in any particular case are too remote to be taken seriously." See id. at 24.

141. In rem "[i]nvolv[es] or determin[es] the status of a thing, and therefore the rights of a persons generally with respect to that thing[,]" as opposed to in personam, which "[i]nvolv[es] or determin[es] the personal rights and obligations of the parties." BLACK's LAW DiCTIONARY 806, 809 (8th ed. 2004).

142. William BlaCKStOne, COMmentaries On the LaWs OF ENGLAND 2 (2d ed. 1992).

143. This is a traditional view of property, also relied on by Adam Smith and Jeremy Bentham. It is in contrast to a more recent view of property rights as a malleable "bundle of rights." Compare ADAM SMITH, LECTURES ON JURISPRUDENCE 9-86 (R.L. Meek et al. eds., 1978), and JEREMY BENTHAM, THE 
broadcasts the rights and obligations inherent therein "to the world." 144 This, in turn, creates a duty in "everyone else" to understand what is being broadcast.

In order to avoid violating another's property rights, [individuals] must ascertain what those rights are. In order to acquire property rights, [individuals] must measure various attributes, ranging from the physical boundaries of a parcel, to use rights, to the attendant liabilities of the owner to others (such as adjacent owners). ${ }^{145}$

Based on this, and drawing from Keppell v. Bailey ${ }^{146}$ (the case that gave us the term "fancy" to describe a prohibited new property form), Merrill and Smith make the point that what the numerus clausus is really doing is making it easier on others to understand what is being broadcast about the ownership rights of others in a particular thing:

There can be no harm to allowing the fullest latitude to men in binding themselves and their representatives, that is, their assets real and personal, to answer in damages for breach of their obligations. This tends to no mischief, and is a reasonable liberty to bestow; but great detriment would arise and much confusion of rights if parties were allowed to invent new modes of holding and enjoying real property, and to impress upon their lands and tenements a peculiar character, which should follow them into all hands, however remote. Every close, every message, might thus be held in several fashion; and it would hardly be possible to know what rights the acquisition of any parcel conferred, or what obligations it imposed. ${ }^{147}$

That is, the courts are concerned that new property interests will create information costs for those third parties that are required by our in rem system to perceive the rights being broadcast from all property. ${ }^{148}$

This is a significant concern for a number of reasons. The first reason is inherent in communication. One must expend resources (i.e., incur cost) in order to receive and correctly interpret communication, and expanding the type or range of information being communicated (i.e., changing what rights

Limits OF JURISPRUDENCE DEFINED 164 (1945), with Felix S. Cohen, The Pragmatic Meaning of Private Property, 9 RUTGERS L. REV. 357, 370 (1954).

144. Merrill \& Smith, supra note 104, at 359.

145. Merrill \& Smith, supra note 16, at 26.

146. Keppell, 39 Eng. Rep. at 1049.

147. Merrill \& Smith, supra note 16, 25-26 (quoting Keppell, 39 Eng. Rep. at 1049).

148. See id. at 26 . 
are possible or potentially present by creating new types of property) will necessarily increase that cost.

The second is the universality described above: the duty to understand is not personal. ${ }^{149}$ It does not focus on one party or even on one class of parties. Instead, it attaches to "everyone else" and is necessary in order to permit people to clearly and efficiently perceive property rights and obligations and to economically arrange their plans accordingly. ${ }^{150}$ Unfortunately, this universality, while helpful and necessary, greatly amplifies the costs of communication because those costs end up being applied both to interested parties and to third parties who presumably have no need to understand the rights and responsibilities of a given property owner or relating to a given piece of real property. ${ }^{151}$

Property owners and those directly interested in a given piece of property will not take adequate account of these third party costs, so the informational burden identified herein is only possible so long as property remains simple and standardized such that "everyone else" can understand the broadcast easily and with little cost. ${ }^{152}$ By honoring the numerus

149. See id

150. See Merrill \& Smith, supra note 104, at 359.

151. See id. Merrill and Smith posit a helpful example, which seems to have been based, at least in part, on a more complex hypothetical set forth by Henry Hansmann and Reinier Kraakman. See Merrill \& Smith, supra note 16, at 27 (citing Henry Hansmann \& Reinier Kraakman, Unity of Property Rights 5, 5-6 (November 17, 1999) (unpublished manuscript) (on file with The Yale Law Journal)). Suppose that many people own watches. One of these people is A, who is the sole owner of one of the watches and who wants to transfer some of his rights to use the watch to B. The law, as we discussed above, permits the creation of various types of estate in property: A could sell a fee, a life estate, or some sort of concurrent interest. But, instead of this, assume that A wants to create a time-share type of interest in the watch, which would allow B to use the watch only on the fifteenth of each month. If this sort of "fancy" property right were permitted, then everyone else interested in buying a watch (whether from A or from any other owner) would have to continually be on the lookout as to whether or not the watch they were interested in had been carved up in this manner or in some other unique manner. Neither A nor B would care about this, as they would have accomplished their purpose and would presumably have accounted for any marginal cost associated with a future sale. By foreclosing anything other than a standardized set of forms, then, property law forces parties to effectively moderate the costs ultimately born by "everyone else."

152. This point about third parties is central to Merrill and Smith's view of the numerus clausus. They focus on the informational asymmetry that arises due to the fact that third parties have no connection with, or exposure to, the transaction wherein the unique property interest is created. See id. at 28 . Those connected with the transaction (i.e., those who fall within the "zone of privity") are able to account for the increased informational costs by incorporating them (or an expectation of them) into the price they receive or pay, and such immediate parties (or those within the "zone of privity" of the decision to create the fancy) could perhaps be just as effectively (and more easily) controlled or affected by a contractarian approach with default rules that can be opted out of. See id. at 28-29, 31. Those not so connected to the transaction, however, do not have the knowledge or ability necessary to act in an informed manner and so do not have that ability. See id. at 30-31. And that it is that disconnect upon which Merrill and Smith focus - that fundamental asymmetry of information drives the numerus clausus as a mandatory rule of prohibition. See id. Interestingly, that may well be (particularly given the amount of interest generated by Merrill and Smith's writings on this matter), but that is not directly 
clausus, then, the law effectively guards against the extraordinary informational costs that would result from recognizing the unendingly unique property rights that parties would develop of their own accord:

Limiting the number of basic property forms allows a market participant or a potential violator to limit . . inquiry to whether the interest does or does not have the features of the forms on the menu. Fancies not on the closed list need not be considered because they will not be enforced. ${ }^{153}$

This standardization lowers the cost of determining the nature of the property rights at issue and so economically benefits society as a whole. ${ }^{154}$

\section{Informational Burdens Compared to the Cost of Heterogeneity}

The costs associated with the informational burdens of property, analyzed by Merrill and Smith and described above, are notably similar to

relevant to the point made by this Article. The relevant point here is that, at least in the view of some, the numerus clausus exists in order to counteract informational burdens created by new or unique property types, and such a cost is very similar to the heterogeneity cost identified herein. The extent to which those costs are borne by those outside the zone of privity is partially analogous, but it is not necessary and does not directly drive the application of the numerus clausus to the heterogeneity of vesting documents. See infra Part III.B.2. In fact, taking it even a step further, the numerus clausus is arguably applicable here regardless of whether or not it directly turns on informational burdens. See, e.g., Heller, supra note 135, at 1176-78. Therein, as was briefly discussed above, Heller argues that the purpose of the numerus clausus is to limit fragmentation of ownership and thus promote the easy transferability of property rights. Id. This is not an informational burden and so is not as similar to the heterogeneity cost identified above as is Merrill and Smith's cost. The numerus clausus would still apply, however, as it still posits that property law should limit newness or uniqueness when doing so would further an underlying goal of property law, and this is the same application urged herein, as applied to vesting document heterogeneity.

153. Merrill \& Smith, supra note 16, at 33. "Perhaps the key point about the numerus clausus is informational: The forced standardization of property forms creates a kind of shorthand which, in turn, reduces information costs." Jonathan C. Lipson, Secrets and Liens: The End of Notice in Commercial Finance Law, 21 EMORY BANKR. DEV. J. 421, 497 (2005). In other words, different people with different rights to a single asset "need some means of assuring that they share a common understanding of those rights." Henry Hansmann \& Reinier Kraakman, Property, Contract, and Verification: The Numerus Clausus Problem and the Divisibility of Rights, 31 J. LEGAL STUD. 373, 382 (2002). Without that, there is potential for the parties to "mistakenly make inconsistent uses of the asset or underuse the asset" or to misallocate resources due to a fear that "the other will . . . opportunistically assert rights that properly belong to the other." Id. A failure to reach such a common understanding will result in the parties taking costly actions to protect their rights, and in a general discouragement in improving and using assets. See id. at 382-83.

154. See Merrill \& Smith, supra note 16, at 33. This may lead to the conclusion that there is a preferred balance as to the economically appropriate number of recognizable property forms. See id. at 39. Some costs would be lowest in a fixed system that only recognizes a single type of property interest. See id. at 40. "On the other hand, by grandfathering in existing forms of property, and permitting legislative creation of new forms, the numerus clausus permits some positive level of diversification in the recognized forms of property." Id. 
the heterogeneity costs described in Part II.B., above. ${ }^{155}$ As such, the lessons that can be drawn from the numerus clausus are relevant to vesting heterogeneity.

As set forth above, the costs identified by Merrill and Smith arise from the in rem nature of property because people must receive and understand the rights and obligations that inhere in property and are thereby broadcast to the world at large. ${ }^{156}$ These costs are a central (perhaps the central ${ }^{157}$ ) part of the numerus clausus theory currently in circulation. That is, Merrill and Smith's positive economic analysis of the numerus clausus ${ }^{158}$ rests upon the conclusion that the informational burdens of new property types (or "fanc[ies]") is what drives our system's tacit adoption of the numerus clausus. ${ }^{159}$

And those informational burden costs are strikingly similar to the heterogeneity costs outlined above. ${ }^{160}$ Those heterogeneity costs are measured by the extent to which vesting document variability increases the cost of (or otherwise detracts from) the underlying purpose of the recording system, which is to make information available to the right parties at the right time. ${ }^{161}$ In a very direct way, this is the same concern as that identified by Merrill and Smith: a concern with the difficulty and expense others will encounter in attempting to understand the ownership rights of a particular piece of property (and the rights and obligations emanating therefrom). ${ }^{162}$

A comparison of examples may serve to demonstrate. First, recall the example set forth above regarding unique property interests in a watch. ${ }^{163}$ As Merrill and Smith point out, if A were permitted to create a new and fanciful type of timeshare interest in his watch, then everyone else interested in buying a watch (from A or from any other owner) would incur

155. See id. at 24-42; see supra Part II.B.

156. See Merrill \& Smith, supra note 16 , at 24-42.

157. See supra note 152. It is clear that Merrill and Smith view their identification of cost as unique from predecessors examining the numerus clausus and, as such, an important part of their contribution.

158. See, e.g., supra note 89 .

159. See Merrill \& Smith, supra note 16, at 33.

Standardization reduces the costs of measuring the attributes of such rights. Limiting the number of basic property forms allows a market participant or a potential violator to limit his or her inquiry to whether the interest does or does not have the features of the forms on the menu. Fancies not on the closed list need not be considered because they will not be enforced.

Id. (internal citations omitted).

160. See supra Part II.B.

161. Id.

162. See Merrill \& Smith, supra note 16, at 24-42.

163. See supra note 151. 
greater cost because they would have to continually be on the lookout for that fancy (or for some other, unknown type of fancy). ${ }^{164}$ This would be exacerbated because neither A nor B (the party desiring to acquire the fanciful interest) would care much about the informational burdens incurred third parties (i.e., the increased cost to the system as a whole).

Now, liken this to a scenario relating to vesting documents. Assume that A owns Blackacre, which is located in a jurisdiction that permits, and heavily favors, deeds of trust. A needs to borrow funds and approaches B for a loan. B desires to lend money to A and to secure the loan with a security interest in Blackacre. Rather than utilizing a deed of trust typical for the jurisdiction, however, B desires to utilize a document called "Claim of Lienhold Interest." The document functions like, and effectively is the same as, a deed of trust: A conveys title to a third party to hold in trust to secure payment of the loan to B. ${ }^{165}$ However, none of the parties are assigned traditional titles in the document itself (i.e., A is not called "trustor," the third party holding title is not called "trustee," and B is not called "beneficiary"), the document is not fashioned similarly to a deed of trust, the purpose of it is apparent only from a very deep and careful reading, and it contains a lot of information about B's company of an advertising nature. Such a document will create costs for others in the same manner as does A's unique timeshare interest in his watch.

For instance, assume that A later puts Blackacre up for sale and that D becomes interested. Part of D's due diligence will certainly include a title review, and heterogeneity will make it harder for $\mathrm{D}$ to find the document. It will do so because the Claim of Lienhold Interest is unique and unlike other documents (which are themselves unlike other documents), so no information from the document can be loaded into a relational database that is efficient or searchable. ${ }^{166}$ Accordingly, D will have to engage in the traditional, and laborious, method of searching for claims on title. ${ }^{167}$ Also, once the document is found, it will be more costly to analyze and understand. ${ }^{168}$

Moreover, as with the informational burden costs analyzed by Merrill and Smith, these costs will be exacerbated in that they will be imposed not just on D, but on "everyone else." Everyone interested in buying real

164. See Merrill \& Smith, supra note 16, at 26-33.

165. See DUKEMINIER, supra note 3, at 619-20 (setting forth the basic functioning of a deed of trust).

166. See supra Part II.B.

167. See supra note 67.

168. That is clear from this hypothetical, which involves a fairly complicated document, but recall from above that this would hold for a simple document existing in a heterogeneous universe, as well. See supra note 100 . 
property in a jurisdiction permitting heterogeneous vesting documents (whether from A or from any other owner) will have to continually be wary as to what documents are recorded against property and what those documents mean. Of course, neither A nor B will care about this, as A will have received her loan, and B will have documented its security interest in the fashion it desires.

We can perceive from these examples, then, that the costs that drive the courts to enforce the numerus clausus in the context of the kinds of property interests permitted are fundamentally similar to the costs that are caused by vesting document heterogeneity. Both forms of cost arise from the rights and obligations inherent in property that must be perceived by others and can be measured by the extent to which other, potentially interested parties must expend time and energy in accessing and understanding that information. This parallel is important because it underscores the similarity of Merrill and Smith's numerus clausus and so supports its application here.

In other words, the numerus clausus, and the lessons that can be drawn from it, should be applied to vesting heterogeneity in order to drive the law in a direction that optimizes efficiency vis à vis other potentially interested parties. The numerus clausus, as applied to property forms, forecloses anything other than a standardized set of property types in order to moderate the costs ultimately born by "everyone else," and it should do the same thing here. It should similarly foreclose heterogeneous documents and drive filers utilizing the recording system toward a standardized set of documents. How that would occur - that is, how the numerus clausus would function here- is addressed in Part IV, below.

\section{A "Vesting Numerus Clausus"}

The numerus clausus analysis developed by Merrill and Smith is meant to explain property law's default hostility to all but the most traditional types of property. Our examination of vesting heterogeneity is similar to their examination of new property types, so an interesting point of consideration is how that analysis would work here. Such an analysis has two elements. The first is to assess what effect the analysis would have if it were applied. The second is to explore how the numerus clausus could come into effect, given the courts' and state legislatures' apparent apathy toward vesting heterogeneity.

\section{A. A Proposed Numerus Clausus Analysis}

If the numerus clausus were applied to vesting heterogeneity, it is reasonable to assume both that the number of categories of potential vesting documents would be reduced and that the content of the categories 
remaining would be simplified. ${ }^{169}$ With respect to a reduction in the number of categories of potential vesting documents, there are countless documents that can be filed in the recording system: deeds, secured interest documents, easements, licenses, covenants, lis pendens, trust documents, death certificates, mechanics' liens, judgments, releases, waivers - the list goes on and on and is bounded only by imagination. ${ }^{170}$ Moreover, each of these documents is merely a broad category, which may itself be constituted of many different sub-types. ${ }^{171}$ Under a numerus clausus analysis, some of these types of documents would simply go away. ${ }^{172}$

From our current standpoint of very high variability, it is impossible to state with any confidence which particular categories or documents would go away. It may be helpful, however, to examine one such category that theoretically would never have been adopted if the numerus clausus had been in effect with respect to vesting documents in the past. As such, let us take a look at what is known as the grant, bargain, and sale deed (a "GBS deed"), as it is utilized in a given jurisdiction (here, Nevada). ${ }^{173}$

169. That the remaining categories would be simplified is highly likely. Standardization and simplification are closely related, as the process of standardizing any sort of input or process generally involves a reduction of the given input or process to its most integral components (i.e., its most simple, functional state). See, e.g., S. Anil Kumar \& N. Suresh, Operations Management 198 (2009). Recall, however, that simplification of the documents is not necessary or integral to cost-cutting, as any standardization will lower the costs involved in reviewing ownership information. See supra note 100.

170. Legal Dictionary, LAW.COM, http://dictionary.law.com/Default.aspx?selected=1751 (last visited July 25,2012) (defining "Record" and stating, "[n]ormally recorded is any document affecting title to real property such as a deed, deed of trust, mortgage, reconveyance, release, declaration of homestead, easement, judgment, lien, request for notice of default, foreclosure, satisfaction of judgment, decree of distribution of a dead person's estates and sometimes long-term leases."). See, e.g., MASs. GEN. LAw sch. 156C, § 66 (West 2012), available at http://www.malegislature.gov/Laws/GeneralLaws/ PartI/TitleXXII/Chapter156c/Section66 (listing as recordable instruments "any deed, lease, notice of lease, mortgage, discharge or release of mortgage, assignment of mortgage, easement and certificate of fact.").

171. For example, one of the categories is deed, but there are numerous types of deeds. There are general warranty deeds, special warranty deeds, and quitclaim deeds, to name a few. See, e.g., DUKEMINIER, supra note 3, at 585-86. Similarly, another category is secured interest documents, which consists of mortgages and deeds of trust. See Treas. Reg. Rule, 26 C.F.R. $\S 1.860$ G-2(a)(5) (2011) (noting "[o]bligations secured by interests in real property include the following: mortgages, deeds of trust ....”).

172. Of course, this depends on when the numerus clausus is applied. This Article attempts to apply the numerus clausus concept to vesting heterogeneity in an original fashion, starting at a theoretical point of time in the past. That is, it does not attempt to analyze the costs inherent in changing the existing suite of vesting documents available in a given jurisdiction. Instead, it examines how the numerus clausus would apply to a given vesting document if it were so applied immediately before that vesting document were adopted or not. To apply the numerus clausus doctrine on a retroactive basis - that is, to ask to what extent it could be utilized to actually roll back the documents now available - would require an analysis different from the one set forth in this section in that such an analysis would have to account for the additional costs associated with upsetting existing practice and expectations.

173. Nevada is not special and merely serves as an example. 
In Nevada, a GBS deed differs from a warranty deed in that it does not come with all of the implied warranties inherent in warranty deeds. ${ }^{174}$ Instead, a GBS deed only creates two covenants: (a) a covenant that, prior to the time of the conveyance, the grantor has not conveyed the same real property, or any right, title, or interest therein, to any person other than the grantee; and (b) a covenant that the real property is, at the time of the execution of the conveyance, free from encumbrances done, made or suffered by the grantor, or any person claiming under him. ${ }^{175}$ This is substantially more limited than the warranty deed covenants. ${ }^{176}$ Additionally, these GBS deed covenants do not run with the land; unlike warranty deed covenants, which benefit later grantees, these covenants benefit the immediate grantee only. ${ }^{177}$

The GBS deed, then, is in the same category as the special warranty or general warranty deed, but it creates different legal obligations and rights. So what kind of effect would the numerus clausus doctrine have here? Recall that, at its most basic, the doctrine would eliminate "fan[cies]."178 But it would not do so indiscriminately. We can see this from the existing numerus clausus and its effect on permissible property types.

174. Warranty deeds carry with them six covenants, or warranties: the covenant of seisen, the covenant of further assurances, the covenant against encumbrances, the covenant of general warranty, the covenant of quiet enjoyment, and the covenant of right to convey. See DuKEMINIER, supra note 3, at 585-90. These differ somewhat, depending on which type of warranty deed is given. Id. The general warranty deed warrants against all defects in title, whenever occurring, and the special warranty deed warrants only against the grantor's own acts. Id.

175. See Cal. Civ. Code $§ 1113$ (West 2011); Nev. Rev. Stat. AnN. § 111.170 (West 2011). In other words, the grantor is promising that she did not convey the property to anyone else and that she has not "done, made or suffered" any encumbrances on it. "Suffered" in this context means "caused to be placed," and any encumbrance within the grantor's "power to prevent" falls within this category. See GeORGe LefCoe, ThOMPSON ON ReAl Property § 94.07(b)(2)(i) (David A. Thomas ed., 2009); Crist v. Fife, 183 P. 197 (Cal. App. 1919).

176. Though the implied covenants set forth in supra note 174, above, are somewhat archaic in nature, and so are somewhat subject to interpretation, it seems patent that these two covenants would not provide any of the benefits of the covenant of further assurances, the covenant of quiet enjoyment, and, most notably, the covenant of seisen. That is, the grantor is not promising good title or even claiming that she owns the property.

177. See LEFCOE, supra note 175, § 94.07(b)(2)(i). Despite this odd mixture of warranty deed covenants and limited duration, the author's experience indicates that the GBS deed is favored over the special warranty deed in Nevada. That means that, if you are doing business in Nevada, you cannot simply rely on local custom and assume that what you are getting is analogous to what you are accustomed to getting. Recall the Introduction, above. See supra Part I. In many ways, this is precisely what this Article is addressing: the costs you must incur every time you deal with real estate due to the fact that so many different categories and sub-types of vesting documents are permitted.

178. In its traditional form, as it has been applied for centuries, it is more accurate to say that it has prevented the creation of fancies. In reality, we are examining a different situation, wherein the numerus clausus has not been applied historically to vesting heterogeneity. We must imagine, then, how the numerus clausus would be applied to a given type of vesting document immediately prior to that document's historical adoption. See supra note 172. 
As Merrill and Smith have indicated, the best way to reduce costs incurred by third parties would be to mandate a single option. ${ }^{179}$ In the case of property forms, it would probably be "a simple usufruct or an undivided fee simple." ${ }^{\prime 180}$ In the case of vesting documents, it would probably be some sort of "notice of interest" that simply indicated that the filer claimed a right in the property. ${ }^{181}$ The problem with this, of course, is that it creates its own costs in that it would frustrate parties' goals and their ability to reach legitimate goals. ${ }^{182}$ That is obviously not desirous, and the standardization enforced by way of the currently operable numerus clausus does not really do that. Though its limitation on cognizable property types may at times frustrate parties, most objectives can be attained by simply combining the relatively limited number of property types that are available. ${ }^{183}$

What we are left with, then, is a doctrine that seeks not maximum standardization, but a balanced level of standardization—one that minimizes the sorts of costs examined above, but that does not completely eliminate creativity and ingenuity. In other words, what we are left with is "optimal standardization." 184 Merrill and Smith represent this in a model of the

179. See Merrill \& Smith, supra note 16 , at 34 .

180. Id. at 35 .

181. Or perhaps, in either case, there would be an extremely limited menu consisting of no subtypes.

182. See Merrill \& Smith, supra note 16 , at 35.

183. See id. (citing Whiton, 473 N.E.2d at 542). Merrill and Smith use the example of a property owner who desires to enter into a lease "for the duration of the war." See id. As discussed above, this type of property interest would likely fail under the numerus clausus. See supra note 110. However, this type of lease could effectively be created by drafting a long-term lease determinable upon the termination of the war. See Merrill \& Smith, supra note 16, at 35. This avoidability does not mean that numerus clausus is either superficial or trivial. Id. As to the former, some have focused on the avoidability of the numerus clausus to argue that the doctrine is an example of "form over substance." See 1 PowELL, supra note 110, $\S 11.01$, at 16-68. However, as Merrill and Smith point out, "this is true only if the measurement costs to third parties of ascertaining the meaning [of a work-around solution] are the same as the costs of ascertaining the meaning of [an entirely new interest.]" See Merrill \& Smith, supra note 16 , at 12 n.29. As to the latter, the ability to work around the numerus clausus creates a cost for those seeking to do so. See id. at 35. They must invest the resources to create a path to their objective, and that required investment acts as a kind of "pollution tax," which will disincentivize such activity and so suppress new and fanciful creations. See id. Ultimately, then, the system drives participants toward standardized components but effectively permits great creativity and ingenuity. Merrill and Smith liken this to language - in both, there are standardized building blocks that cannot generally be discarded but that can be utilized in a recursive fashion to create a literally infinite number of possibilities and that can permit significantly more complex structures to be fashioned therefrom. See id. at 35-36.

184. Hence the title of Merrill and Smith's work upon which this author has so consistently, and gratefully, drawn. The concept arises when one views standardization as a spectrum. See id. at 38 . On one end is total and mandatory standardization, with the frustration costs discussed above, and on the other end is total freedom of customization, with the informational costs discussed above. See Merrill \& Smith, supra note 16, at 38 . Optimal standardization lies somewhere in the middle of this spectrum. See id. 
choice of the number of property forms, from which the following is derived: ${ }^{185}$

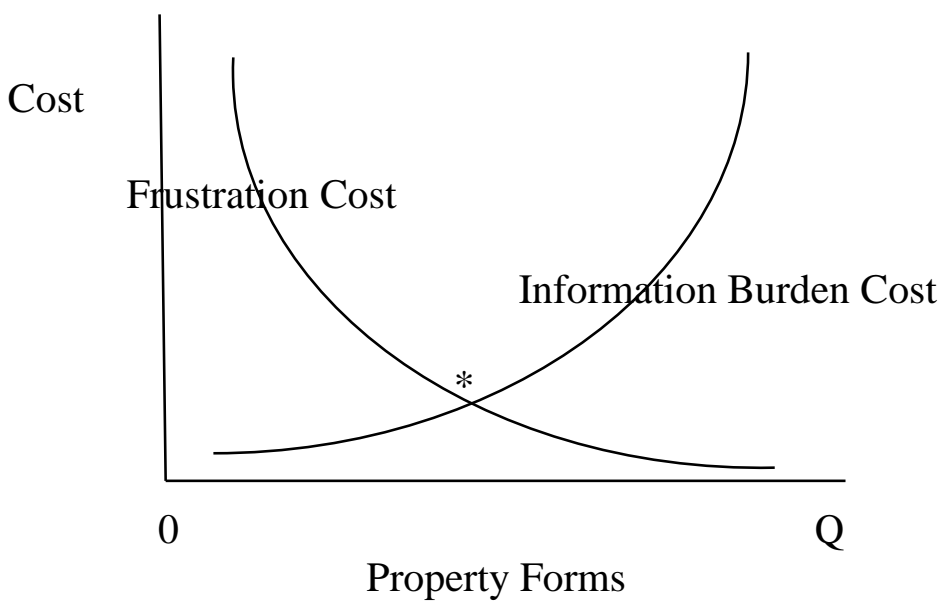

The $\mathrm{x}$-axis is the number of property forms permissible. It starts at 0 and ranges up to $\mathrm{Q}$, which represents the number of property forms that would exist in a system with no standardization constraints. It assumes that the most simple and widely utilized property forms (i.e., the fee simple and the like) will be adopted first (closer to 0). The y-axis is the generic cost incurred by society; the lower on this y-axis, the better, as lower cost means higher social wealth and well-being. As is shown on the model, this permits the representation of two separate cost curves. One, the "information cost curve," measures the costs caused by the different permissible property forms. It starts near 0 on the $\mathrm{x}$-axis. As the number of forms increases beyond the simplest property forms, this curve increases at an accelerating pace. That is, the marginal information costs increase as more specialized, more complicated, and more confusing property forms emerge. ${ }^{186}$ The other, the "frustration cost curve," measures the frustration cost caused by the different permissible property forms. It starts high on the y-axis and moves toward 0 at an accelerating pace as the permissible number of forms increases. That is, the marginal frustration costs increase as fewer and

185. See id. The model set forth herein differs from that of Merrill and Smith, but this discussion is drawn from their model and analysis of the same.

186. It is a curve because the marginal costs of information increase as property forms become more exotic and hence more and more difficult to access and understand. 
fewer property forms are allowed such that parties are less and less able to freely structure their relationships and arrangements. ${ }^{187}$

Merrill and Smith contend that the numerus clausus, by creating a presumption against new forms of property types, balances the need to brake parties' creativity with a recognition of long-settled property rights and legislative creativity. ${ }^{188}$ Though they do not contend that the numerus clausus has created a current ideal number of property forms (or even that there is a truly singular optimal), they do believe that the numerus clausus pushes the system toward the hypothetical point * (from the model above), which is where overall costs are minimized. ${ }^{189}$

The same would happen in if the heterogeneous GBS deed were judged pursuant to a "vesting heterogeneity numerus clausus." There, the operative agent of judgment ${ }^{190}$ would engage in an optimization analysis. The analysis would involve determining, in some fashion, whether the GBS deed decreases frustration costs by an amount that is greater than its concomitant increase in informational burden costs.

A model of the type discussed above would again be relevant. Indeed, in a world wherein the numerus clausus were applied to vesting heterogeneity, we could modify the model as follows:

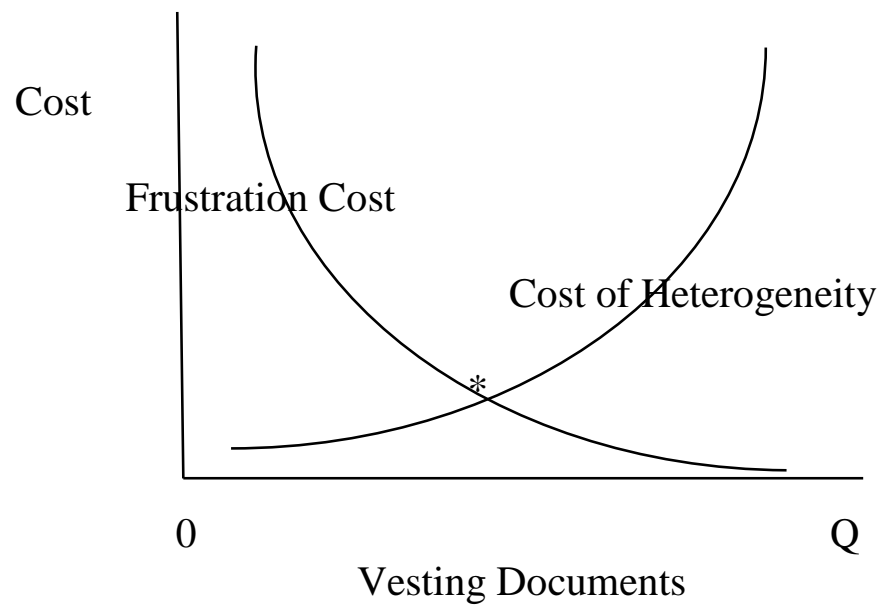

187. It is a curve because the marginal costs of frustration decrease as property forms become more varied in that, beyond a certain point, each additional property form permits relatively less and less creativity.

188. See Merrill \& Smith, supra note 16 , at 40.

189. See id.

190. See infra Part IV.B. 
The $\mathrm{x}$-axis, this time, is the number of categories and sub-types of vesting documents permissible. It starts at 0 and ranges to $\mathrm{Q}$, which represents the number of categories and sub-types of vesting documents that would exist in a system with no standardization. It assumes that the most simple and widely utilized property forms (i.e., a general warranty deed) will be adopted first (closer to 0). As above, the y-axis is the generic cost incurred by society. Again, these two axes permit the representation of two cost curves. The frustration curve is the same as above. The cost of heterogeneity curve is similar to that discussed above, but instead of tracking information burden cost, it tracks the costs of heterogeneity discussed herein. ${ }^{191}$

Our vesting heterogeneity numerus clausus, then, would seek to determine whether a world with the GBS deed is at, or to the left of, point *. If it is, then it makes sense to permit it. The frustration costs associated with losing the unique characteristics and attributes of the GBS deed ${ }^{192}$ exceed the heterogeneity costs created by the addition of yet another type of vesting document, so the world would be better off with this type of document. If it is to the right of this point, however, it does not make sense to permit this type of document. The frustration costs associated with losing the unique characteristics and attributes of the GBS deed are less than the heterogeneity costs created by the addition of the GBS deed to our recordable oeuvre, and the world would be better off without the new document. ${ }^{193}$

Though it is mere speculation to surmise how the GBS deed would have been judged under such an analysis, it may be possible to more accurately examine how another vesting document would have been judged, given that its evolution and adoption are relatively recent and well understood. That document is the trust deed.

Historically, creditors with security interests in real estate utilized (i.e., recorded) mortgages. ${ }^{194}$ These became problematic, however, as courts of equity instituted the "equity of redemption," which permitted borrowers to take back possession of a foreclosed property even after the foreclosure

191. As above, both of these are curves because the costs at issue marginally increase or decrease in synch with the $\mathrm{x}$-axis.

192. See supra note 177 and accompanying text.

193. Recall that this does not mean that parties are simply out of luck if they really need to, or desire to, impart the ownership attributes associated with a GBS deed. In such a situation, the parties could simply convey by some other deed and specify within the language of the deed itself that only certain covenants are made or implied. This would permit the parties to achieve their objective but still serve the purpose of the numerus clausus by disincentivizing fanciful documents. See supra note 184.

194. See DUKEMINIER, supra note 3, at 616-21. 
sale. ${ }^{195}$ For obvious reasons, this right was problematic for creditors, and they immediately sought a way to avoid it. ${ }^{196}$ They soon found it, when the courts of law intervened and blocked the equity of redemption after a judicially supervised foreclosure sale. ${ }^{197}$ Such a sale, however, required a lawsuit and attorneys and all of the additional expense and effort associated with legal remedies. As such, attorneys settled upon a substitute document, the trust deed, as a way to minimize cost but still avoid the equity of redemption. ${ }^{198}$ It did so by permitting a sale (the key element necessary to avoid the equity of redemption) without the involvement of the courts. ${ }^{199}$ In other words, the deed of trust proved to be uniquely useful and suitable to the task at hand.

This development seems to fit neatly into the optimization analysis associated with the numerus clausus and embodied in the models set forth above. Because this document arose in direct response to a limitation (or perceived limitation) inherent in the existing suite of documents, we can see why it was created and how it gained such widespread application. As such, it seems relatively plausible to balance that interest (or, in other words, the cost that exists absent the document) against the cost of introducing an additional vesting document into the system. And, doing so, it seems likely that a vesting heterogeneity numerus clausus would have permitted such a document, as the frustration costs (not being able to avoid a costly and difficult foreclosure process) credibly seem to exceed the heterogeneity costs (the difficulty incurred by everyone else due to the addition of an additional secured lending vesting document). In other words, the trust deed does not push the system to the right of point *.

This, then, is how a vesting heterogeneity numerus clausus could take effect. ${ }^{200}$ In much the same way that the numerus clausus has put a brake upon individual creativity in the name of wider efficiency, and so strongly reduced the number of potential property forms, it could do the same here. It could counteract the historical trend of the recording system, which has been so open to unbridled creativity, and limit new vesting documents when the heterogeneity costs incurred exceed the frustration costs of the prohibition. How, though, could this type of analysis come to bear? In the context of property forms, the agent of implementation has been the court

195. See id.

196. See id.

197. See id

198. See id.

199. It accomplished this by having the owner/borrower place the property into trust for the benefit of the lender and with directions to the trustee to sale the property if the owner/borrower defaulted on her obligations. See DUKEMINIER, supra note 3, at 619-20.

200. Again, if it were applied prospectively. See supra note 172. 
system. $^{201}$ The courts have shown no parallel inclination here, ${ }^{202}$ though, so any potential numerus clausus analysis would have to come from another source.

\section{B. How to Institute the Numerus Clausus Here}

Initially, it seems reasonable to believe that the institution of a numerus clausus type of doctrine should come from the legislature. With the courts having failed to insinuate themselves into this property law issue (perhaps due to a deference to the legislative nature of the recording system) ${ }^{203}$ it seems as though legislatures could lay down rules or prohibitions regarding what categories or sub-types of vesting documents are permissible. This would seem particularly apt given that legislatures seem more capable of making the highly qualitative types of judgments that suppression (or not) of private creativity involves. ${ }^{204}$ But they too have failed to speak to this issue, perhaps believing the record systems function "well enough," given their historicity. ${ }^{205}$ Whatever the cause of this abdication of responsibility, it means that some other source will have to provide the impetus or grounding behind any potential numerus clausus effect on vesting documents.

One possibility is the free market. A market-based source of vesting documents could conceivably become significant enough that it could create and foster a system of "network effects" so influential as to drive parties

201. See Merrill \& Smith, supra note 16, at 9-10 (discussing the numerus clausus as a "norm of judicial self-governance.").

202. Why the courts have shown so little inclination to limit the types of vesting documents is not entirely clear, though it seems reasonable to believe that this reluctance may be tied to the fact that the entire recording system is a legislative construct. See supra Part II.A. If the courts are willing to permit legislatures to avoid the numerus clausus in the property form context (or unable to stop legislatures from doing as much), then it seems likely that they would be similarly unwilling to reduce the range of potential document choices when those choices seem to arise from, and be approved by, a legislative system.

203. See id.

204. See, e.g., Emily Hammond Meazell, Scientific Avoidance: Toward More Principled Judicial Review of Legislative Science, 84 IND. L. J. 239, 262 (2009) (“[L]egislatures are better situated, at least in the abstract, to consider issues of a non-binary, or qualitative nature."). We can see this sort of respect for the legislature's prerogative in the manner in which various property forms have come into being. See, e.g., Merrill \& Smith, supra note 16, at 15-16 (discussing the legislative nature of time-shares); DUKEMINIER, supra note 3, at 264-70 (discussing the legislative creation and evolution of executory interests).

205. But see ARIZ. REV. STAT. ANN. § 11-480 (West 2010) (setting forth similar requirements, including that each document have a caption stating the nature of the document); UTAH CODE ANN. § 57-3-101 et seq. (West 2010) (setting forth some requirements for documents to be recorded). These statutes set forth minimum requirements, and that is better than a wholly unregulated system, but there is far too much left to discretion and more than enough potential variability to ensure that the heterogeneity costs discussed above are not avoided. 
toward standardization. Network effects exist when one party's adoption of a particular format or standard has positive consequences for other adopters of the same. ${ }^{206}$

The value of a particular form of communication or technology - the English language, for example, or the Macintosh computer operating system - increases with the number of people who share that means of communication. The more people who learn a particular language or adopt a given operating system, the more useful that language or operating system becomes. An increase in the number of people who learn the language creates more opportunities for communication, while an increase in the number of people who use the operating system promotes the production of a greater variety of compatible software at lower prices. In both cases, as the size of the network increases, the utility of the network itself increases. These increases in the value of network membership not only confer benefits upon existing users, but also encourage additional users to join, which in turn drives up the value of network membership even further. ${ }^{207}$

This effect can apply to legal standards as well. ${ }^{208}$ When a particular standard of process reaches this point, it becomes self-reinforcing: the more people that adopt the standard or format, the more value there is to continue to do so. ${ }^{209}$

Keeping this in mind, it seems conceivable that a market-based organization could promulgate a relatively compact series of vesting document forms and ultimately become so popular as to become a sort of de facto standard. The source would have to be sensitive to market forces and provide parties the documents they need and desire, but could do so with an inclination toward qualitative and quantitative simplicity. Such a source of vesting documents, if it became entrenched enough, could supply a significant percentage of all vesting documents recorded and so become known as a safe and essential place to locate documents any time one is in

206. See David S. Law \& Mila Versteeg, The Evolution and Ideology of Global Constitutionalism, 99 CAL. L. Rev. 1163, 1183 (2011) (citing, in relevant part, L. Carl Shapiro, Systems Competition and Network Effects, 8 J. ECON. PERSP. 93, 94 (1994)).

207. See id. (footnotes omitted).

208. See id. at 1184.

209. An example would be the widespread popularity of incorporating in Delaware- the more corporations incorporate there, the more accepted it becomes to do so, and the more comfortable people come to be with Delaware as a state of incorporation. See id. Eventually, people expect parties to incorporate there because it has a polished, well-developed body of corporate law and because it is just "the thing to do." 
search of a form to record. ${ }^{210}$ Such a singular source is plausible without government intervention, given the existence, and increasingly important nature, of the internet. ${ }^{211}$ Without court order, statute, or regulation, that organization could become the standard source of vesting documents and, over time, effectively impose a vesting heterogeneity numerus clausus wherein there is so much utility behind using and adopting the forms from the organization (or, put another way, so much disutility in not using and adopting the forms from the organization) that new vesting document categories and sub-types become virtually prohibited. ${ }^{212}$

Admittedly, such a system would not be perfect and would not as strongly funnel society toward standardization as would the courts or the legislature. ${ }^{213}$ However, it would be better than nothing, which is what we have now, and it could, if it gained significant traction, have a systemic effect on the choices parties make when choosing to record. ${ }^{214}$

\section{CONCLUSION}

Vesting documents are easily forgotten, as they seem a basic, unremarkable element of the American recording system and its focus on the provision of information to interested parties. Because of this, it is generally taken for granted that parties are permitted to record virtually anything they want. This vast heterogeneity makes sense, given the history

210. Given the current status of the system, this system would conceivably function in two ways. First, and most importantly, it would stop new documents from proliferating. Second, it would cause unpopular and little-utilized documents in current circulation to atrophy and drop out of use when market demand ceased to justify their use.

211. Such a system would also have the benefit of putting the choice, effectively, within the market's hands. Rather than rely on courts or legislatures to determine what is or is not a useful addition to, or subtraction from, the suite of possible document types, the markets would be able to so decide. In effect, the Internet would permit the voices of "the market" to speak as one on this singular topic.

212. Merrill and Smith touch upon network effects, but they do so to rebut it as a potential objection to the numerus clausus. See Merrill \& Smith, supra note 16, at 45-49 (setting forth the hypothetical objection that "mandatory standardization [is] unnecessary [because] standardization will occur spontaneously"). This seems a rather odd point for them to make. Their discussion of the numerus clausus, so well done, arises from a positive perspective - that is, it is a description of why the law functions the way that it does. That this might also happen outside of the courts' reach seems no serious reason to question it happening within it. The numerus clausus is, in effect, a free-standing doctrine, which either exists or does not, and the fact that it has been effected via the courts is not central to the functioning of its precepts.

213. See Merrill \& Smith, supra note 16, at 46 (pointing out that any form of standardization that is not government-mandated will be, by definition, less capable of lowering the information burden costs outlined herein because even a relatively small rate of non-standardization will effectively pollute the system by sewing uncertainty).

214. There are various examples of technology companies, for example, that have become so close to standard that everyone else can generally be assumed to be familiar with them enough that potential users or consumers likely have a high degree of confidence that these companies' products are readily perceivable and understandable. These include Microsoft, Google, and others. 
of recording system, which evolved in an ad hoc fashion with the relatively modest goal of permitting interested commercial actors who need ownership information to obtain that information in a reliable manner, and the development of different vesting documents over time.

This does not mean, however, that heterogeneity is without cost. In fact, the goal of the recording system is significantly undermined by the extent to which this heterogeneity makes it difficult for parties to gather useful information. Borrowing from extant research in database theory, this Article concludes that the lack of uniformity in vesting documents ensures a costly and inefficient system, a fact exacerbated by the fact that these costs are systemically imposed upon parties other than those who benefit from the heterogeneity that causes the costs.

These costs are interesting in and of themselves and also because they bring to bear a related doctrine, known as the numerus clausus. This doctrine, well-known in legal literature, is an economics-based explanation for the fact that our legal system routinely rejects attempts to create new types of property interests and so funnels real estate dealings into a relatively narrow set of historically accepted property forms. The doctrine is driven by a concern for the informational burdens that new property types create and impose on others.

This doctrine, then, has application here. The numerus clausus, used to describe the law's requirement of uniform property forms based upon a desire to permit others to efficiently perceive ownership information, could easily apply to a hypothetical requirement of uniform vesting documents based upon the same desire. If it were so applied, it would likely operate in the same fashion, restricting creativity generally, but permitting new property forms when the benefits of doing so would outweigh the costs inherent in acknowledging a new property form. One way this could happen here is via the free market, which could utilize relatively novel technology and resources to create a self-policing and reinforcing network of vesting document forms.

If such a thing were to occur, the system would be significantly improved. No longer would parties be free to fashion unique and difficult to understand documents to reflect ownership rights or claims. This would immeasurably improve the recording system's ability to accomplish its purpose of providing information, something that is sorely called for. 